\title{
THE ROLE OF COST IN EDUCATIONAL DECISIONMAKING FOR THE HANDICAPPED CHILD
}

\author{
Katharine T. BARTLETT*
}

Do the 30 million Americans afflicted with physical or mental handicaps have a right of access, no matter what the cost, to all publically sponsored activities? That is now a central question because the price of such access promises to become very great. ${ }^{1}$

\section{INTRODUCTION}

\section{A. The Issue of Cost in Special Education}

Special education for the handicapped is expensive. ${ }^{2}$ Estimates of the average cost of educating a handicapped child are about twice as high as the cost of educating a nonhandicapped child, with some educational placements costing six times as much or more. ${ }^{3}$ Neither the guarantee of a free and appropriate education to handicapped children set forth in the Education for

Copyright $(\mathcal{C} 1985$ by Law and Contemporary Problems

* Associate Clinical Professor of Law, Duke University. I am indebted to Chris Schroeder and Judith Wegner for their insights during numerous conversations $I$ had with them while I was writing this article, and to Richard Boulden, Matt Lavine, and Howard Vingan for their research assistance.

1. Hicks, Should Every Bus Kneel? in Disabled People as Second Class Citizens 13-14 (1982) (quoting Must Every Bus Kneel to the Disabled?, N.Y. Times, Nov. 18, 1979, at 18E).

2. See Oversight of P.L. 94-142 - The Education for All Handicapped Children Act, Part 1: Hearings before the Subcommittee on Select Education of the Committee on Education and Labor - House of Representatives, 96th Cong., lst Sess. 82 (1979) (statement of Walter Tice, American Federation of Teachers); J. Kakalik, W. Furry, M. Thomas \& M. Carney, The Cost of Special Education 5 (1981) [hereinafter cited as KAKALIK] ( $\$ 3577$ average cost per student for handicapped child in 1977-78; $\$ 4898$ average cost in the following 3-year period). Residential placements, not included in the Kakalik study, are even more expensive. See Stark, Tragic Choices in Special Education: The Effect of Scarce Resources on the Implementation of Pub. L. No. 94-142, 14 CoNN. L. REv. 477, 491, 493 (1982). A residential placement may cost well over $\$ 50,000$ per year. See Clevenger v. Oak Ridge School Dist., 744 F.2d 514, 517 (6th Cir. 1984) (ordering residential placement costing $\$ 88,000$ per year); Stanger v. Ambach, $501 \mathrm{~F}$. Supp. 1237, 1241-42 (S.D.N.Y. 1980) (discussing residential placement that would cost at least $\$ 52,410$ for the $1980-81$ school year).

3. KaKaliK, supra note 2 , at 339,343 . (This study noted that, depending on the type of handicap and educational placement (excluding residential placements), the cost of educating a handicapped child is between .49 (full-time work placement for learning disabled students) and 6.78 (regular class plus part-time special teacher) times the cost of educating a nonhandicapped child. See also M. Moore, L. Walker, \& R. Holland, Finetuning Special Education Finance 50-51 (1982) [hereinafter cited as MOORE, Walker \& Holland] (depending upon the type of handicap and method of computation, the cost of special education ranges from 1.37 to 5.86 times the cost of a regular education); Marriner, The Cost of Educating Handicapped Pupils in New York City, 3 J. Educ. Fin. 82, 86-88 (1977) (average cost of special education was $\$ 5897$ per student, compared to $\$ 2294$ per student for a regular education; average per student cost of special education ranged from $\$ 4022$ to $\$ 14,072$, depending on the program). The factors considered in measuring the cost of special education are discussed in MOORE, Walker \& Holland, supra, at 45-58. 
All Handicapped Children Act of 1975 (EAHCA) ${ }^{4}$ nor the prohibition of exclusion of the handicapped from a program or activity receiving federal assistance, contained in section 504 of the Rehabilitation Act of 1973,5 is expressly qualified by considerations of cost. Nevertheless, as the cost of special education has risen dramatically, ${ }^{6}$ and as public concern for the quality of public education generally has sharpened, ${ }^{7}$ cost is often a major factor in educational decisionmaking affecting handicapped children. A school district may understand that certain services sought by parents on behalf of a handicapped child would be extremely beneficial to the child, but nevertheless be concerned about the resource implications of those services. If it determines that it is "unable" to provide those services, it may reject the parents' request. If this rejection is challenged by the parents under the hearing procedures of the EAHCA, the hearing officer's understanding of the relevance of cost may determine whether a program is deemed required by the EAHCA. ${ }^{8}$

Despite its importance, the cost issue is unsettled. Judicial responses range from the position that cost should not be considered in decisionmaking under the EAHCA to the position that cost is an important factor to be taken into account so that a requested program that is "too" expensive need not be offered. Rather than facing the cost issue head on, some courts take cost into account indirectly in making such substantive statutory interpretations as whether a particular requested program is "educational," or whether an educational program is "appropriate," the "least restrictive alternative," or a "related service."

The absence of a clear answer to the cost issue is not surprising. The rights of handicapped children to public education, like other rights established in the 1960's and 1970's, were created without serious attention to

4. Pub. L. No. 94-142, 89 Stat. 773 (1975) (codified as amended at 20 U.S.C. $\$ \S 1400,1401$, $1405,1406,1411-20,1453$ (1982)). The Act applies only to those states that accept federal funds pursuant to its provisions. Id. $\S 1412$. All states now accept federal funds under the Act and are covered by it. See Levinson, The Right to a Minimally Adequate Education for Learning Disabled Children, 12 VAL. U.L. REv. 253, 277 n.135 (1978) (all states except New Mexico submitted state plans under the EAHCA); 1983-84 Educ. HANDicapped L. REP. (CRR) SA:104 (New Mexico legislature passed legislation requiring state board to submit a plan for EAHCA funds).

5. 29 U.S.C. $\$ 794$ (1982).

6. See Stark, supra note 2, at 487 (In the 3-year period after passage of the EAHCA, "local school budgets for special education rose at the rate of 14 percent per year, twice as rapidly as overall operating budgets for public schools nationwide.")

7. In 1983 there were three major studies on how to improve the quality of public education in the United States: Nat'l Commission on Excellence, A Nation at Risk: The Imperative for EduCATIONAL REFORM (1983); Report of the Twentieth Century Fund Task Force on Federal Elementary and Secondary Education Policy, reprinted in Making the Grade (1983); Task Force on Education for Economic Growth, Education Commission of the States, Action for Excellence: A Comprehensive Plan to Improve Our Nation's Schools (1983).

8. See Note, Board of Education v. Rowley: Handicapped Children Are Entitled to a Beneficial Education, 69 Iowa L. REv. 279, 287-88 (1983) [hereinafter cited as Note, Board of Education v. Rowley]; Stark, supra note 2, at 519-20; Note, Enforcing the Right to an "Appropriate" Education: The Education for All Handicapped Children Act of 1975, 92 HaRv. L. REv. 1103, 1109,1125 (1979) [hereinafter cited as Note, Enforcing the Right]; Note, Defining an "Appropriate Education" Under the Education for All Handicapped Children Act, 34 ME. L. REv. 79, 91, 96-97 (1982) [hereinafter cited as Note, Defining an "Appropriate Education"']. 
their redistributive consequences. ${ }^{9}$ Declining to face these consequences when the rights were initially defined might have been appropriate, or at least sound advocacy, for some solutions to issues of implementation and resource allocation which now deserve serious consideration would have been rejected as "unrealistic" when the needs and potential of handicapped were so little understood. A decade later, however, the failure to confront these issues suggests naivete rather than political astuteness and risks the dilution of those rights which the EAHCA was designed to secure. ${ }^{10}$ Consolidation of rights during this "second generation" period depends in large part upon how well their implications, including those of cost, are understood and addressed.

\section{B. The Concept of Program Parity}

I conclude in this article that cost is a legitimate factor to consider in determining the level of educational services to make available to handicapped children, as it is in determining the level of other public services. Moreover, the issue of cost should be confronted directly in educational decisionmaking, not hidden behind an analysis that purports to focus entirely on educational factors. The article focuses on the limits that should be put on considering cost in educational decisionmaking for the handicapped. I argue that although it is appropriate to take cost into account, cost considerations should not prevail to deny a handicapped child an education program that is comparable in quality to that provided to nonhandicapped children. This standard, which I refer to as "program parity," is similar to suggestions that educational programs for

9. Compare Goldberg v. Kelly, 397 U.S. 254, 261, 265-66 (1970) (establishing right to hearing before termination of welfare assistance benefits despite costs to government) with Matthews v. Eldridge, 424 U.S. 319, 334-35, 347-48 (1976) (decided six years after Goldberg v. Kelly and instituting, in cases involving termination of Social Security disability payments, a test balancing private and governmental interests, including administrative inconvenience and cost, to determine extent of due process required).

Legislation on behalf of the handicapped, such as the Urban Mass Transportation Act, 49 U.S.C. $\S 1612$ (1982), and section 504 of the Rehabilitation Act of 1973, 29 U.S.C. $\$ 794$ (1982), has had particularly acute financial consequences, because of the increased costs of providing to the handicapped services that are generally available to others. See, e.g., Dopico v. Goldschmid, 687 F.2d 644 , 650 (2d Cir. 1980) (New York City should have spent six million dollars in Urban Mass Transportation Act Funds in 1980 to make public transportation accessible to the handicapped); Barnes v. Converse College, 436 F. Supp. 635, 638, 639 (D.S.C. 1977) (sign-language interpreter ordered for deaf student to cost about $\$ 1000$ for one summer school session).

The financial consequences of the EAHCA did not go unnoticed in Congress. See, e.g., 121 Cong. REC. 9498-99 (1975) (remarks of Senator Dole) ("Someone will have to pay for [individualized conferences], of course, and that someone will be you and me, the taxpayers."); id. at 9506 (remarks of Senator Baker) ("It is my feeling. . .that [the EAHCA], which contains authorizations in excess of $\$ 6$ billion over a 4-year period, holds out the hope of a level of Federal support which is much greater than we are able to provide during this time of fiscal constraints."). The role of cost in defining the extent of the states' obligation to educate the handicapped, however, was not specifically addressed.

10. The Reagan Administration, partly in response to the financial stress claimed to have been caused by the EAHCA, has proposed several changes in the legislation. See Stark, supra note 2, at 524-28; see also Note, Education - Board of Education v. Rowley: The Supreme Court Takes a Conservative Approach to the Education of Handicapped Children, 61 N.C.L. REV. 881, 897 n.156 (1983) (drawing a connection between the financial crisis created by the EAHCA and a predicted backlash against special education); Comment, Statutory Mandate for "Free and Appropriate Public Education" Satisfied When Handicapped Benefit from Specialized Instruction and Support Services, 14 RUTCERS L. REV. 989, $1004-06$ \& n.90 (1983) (Rowley decision and efforts to erode EAHCA have a financial basis). 
the handicapped be comparable to those of the nonhandicapped;11 a closer examination of this standard and an analysis of its implications should enhance its appeal to policymakers and courts. It is the standard that best interprets the Act, and although it will require some redirection of the approach adopted by the United States Supreme Court in its first attempt at interpreting the Act, ${ }^{12}$ this redirection is consistent with the institutional concerns to which the Court has been sensitive.

Program parity describes a model in which the educational needs of the handicapped child are met in the same proportion as the needs of the nonhandicapped child. It requires that sacrifices, if necessary, be equal. ${ }^{13}$ It does not require dollar-for-dollar cutbacks in every educational program to adjust to resource shortages, but rather a downscaling that keeps programming for handicapped children at a level of quality comparable to that for the nonhandicapped. The standard of program parity thus demands that before cost is used to deny a service that would be beneficial to the handicapped child, school districts must ensure that the handicapped child's needs are met by a program that is at least comparable in overall quality to that offered to nonhandicapped children.

The program parity standard fills a gap between the nondiscrimination mandate of section 504 of the Rehabilitation Act and the affirmative requirements imposed by the EAHCA. These statutes are often read restrictively. The EAHCA has been held to ensure only a minimal level of educational benefit for handicapped children, without relation to the level of educational services afforded to others. ${ }^{14}$ Section 504 has been held to require "equal"

11. See, e.g., Note, Enforcing the Right, supra note 8, at 1125 (proposing that appropriateness under the Act be defined "in relation to the actual level of educational services provided for most children within a given school system" (footnote omitted)); Colley, The Education for All Handicapped Children Act (EHA) A Statutory and Legal Analysis, 10 J.L. \& EDuc. 137, 147 (1981) ("If the optimum level of services can not [sic] be provided within the resources available to a district, then every child (handicapped and non-handicapped alike) within the district must suffer a derogation of his program in relation to his educational potential."); Note, Defining Appropriate Education for the Handicapped: The Rowley Decision, 27 ST. LouIS U.L.J. 685, 705 (1983) ("For the present, the best approach for school districts may be a good faith attempt to educate the handicapped and the nonhandicapped on the same plane.") [hereinafter cited as Note, The Rowley Decision]; Note, Defining an “Appropriate Education," supra note 8, at 109 ("provision of . . . equal educational opportunity necessary requires a comparison between that quantum of opportunity afforded to handicapped and nonhandicapped children.").

12. Board of Educ. v. Rowley, 458 U.S. 176 (1982).

13. See B. Ackerman, Social Justice in the Liberal State 237-38, 261, 270 (1980). Ackerman's discussion of the concept of negative compensation is particularly applicable to rules relating to the handicapped.

"The principle of negative compensation requires $\mathrm{X}$ to receive an education and transactional system that permit him to explore those (perhaps very limited) options that his genetic equipment leaves open for him. These compensatory systems, moreover, need not be perfect, for the resources provided even 'normal' children hardly provide them with an ideally liberal education or perfectly flexible system of transactions. Instead, negative compensation insists that $\mathrm{X}$ be provided with a chance of realizing his genetic possibilities that is no less imperfect than that provided others."

Id. at 270 (italics in original).

14. Board of Educ. v. Rowley, 458 U.S. 176, 201, 203 (1982) (EAHCA requires only specialized instruction and related services which are individually designed to provide educational benefit to the handicapped child). See infra notes 125-28 and accompanying text. 
access, but not affirmative efforts to assure that access is meaningful. ${ }^{15}$ The concept of program parity reads into the affirmative mandate of the EAHCA a comparative standard, akin to the nondiscrimination prohibition explicit in section 504, directing that meaningful educational services be provided to handicapped children at a level determined in accordance with the level of services given to the nonhandicapped.

Because the EAHCA is the detailed statute, drafted specifically to handle educational decisionmaking for the handicapped, and under which most cases challenging the denial of educational services to the handicapped are brought, analysis will be focused primarily on this statute. The EAHCA requires that handicapped children be given a "free appropriate public education." 16 I contend in this article that this requirement must be interpreted by reference to a standard of fairness that relates to the educational services made available to the nonhandicapped. This contention does not depend upon a fusion of the EAHCA with section 504, nor upon an interpretation of the rather murky legislative history of the EAHCA. ${ }^{17}$ It is derived, rather, from a recognition of the inherently flexible and necessarily interactive quality of the concept of "appropriate education." It is often said that the concept of equality has little or no meaning without reference to standards defining substantive rights. ${ }^{18}$ Whether or not this proposition is fully correct, or helpful, it is my view that there are certain substantive rights, among them "appropriate education," that can be given sensible meaning only by reference to a comparative norm or a concept of equality.

In developing the concept of program parity, the term "parity" is used instead of "equality" to avoid the confusion that may arise from common usage of the latter term. Equality is sometimes understood to require not only that alikes be treated alike but also that unalikes be treated unalike. ${ }^{19}$ Insofar as handicapping conditions may involve characteristics that make individuals unalike with respect to a particular service or activity, the term equality might be misunderstood to be intolerant of differences in treatment (inequality) on one level, required to achieve equality on another level. Parity in this article refers to a form of equality respecting claims to educational

15. Southeastern Community College v. Davis, 442 U.S. 397, 413 (1979); Timms v. Metropolitan School Dist., 722 F.2d 1310, 1317 (7th Cir. 1983); Monahan v. Nebraska, 687 F.2d 1164, 1170 (8th Cir. 1982), cert. denied, 460 U.S. 1012 (1983); see Sanders v. Marquette Pub. Schools, 561 F. Supp. 1361,1371 (W.D. Mich. 1983) (a plaintiff is not "otherwise qualified" under section 504 "if accommodating the plaintiff would impose an undue burden on the defendant"); see also infra at 30-31. Numerous cases brought under both section 504 and the EAHCA have reserved judgment on section 504, applying instead the more specific provisions of the EAHCA. See infra note 128. Where relief is granted under EAHCA, the U.S. Supreme Court has held that section 504 is inapplicable. Smith v. Robinson, 104 S. Ct. 3457 (1984).

16. 20 U.S.C. $\$ 1412(1)(1982)$.

17. See infra note 187 .

18. See, e.g., Westen, The Empty Idea of Equality, 95 Harv. L. REv. 537 (1982); Joseph, Some Ways of Thinking About Equality of Opportunity, 33 Western PoL. Q. 393, 399-400 (1980).

19. See Westen, supra note 18, at 539-40, 572; H.L.A. Hart, The Concept of Law 155 (1961); cf. Tigner v. Texas, 310 U.S. 141,147 (1940) (" $\mathrm{t}]$ he Constitution does not require things which are different in fact or opinion to be treated as though they were the same."). 
resources for handicapped children that will often need to reflect important differences between handicapped and nonhandicapped children.

The differences between handicapped and nonhandicapped children are important in defining a relationship between them - a relationship in some senses more difficult to define than that between the majority and other minority groups. Many problems exist in implementing the goal of equal educational opportunity for racial and ethnic minorities and for women. In the abstract, however, there is general agreement that members of these groups should be allowed to advance on the basis of their own merits, unhindered by inherently unequal separate schools, tracks, or programs, which are often motivated by prejudice or discriminatory purpose. This consensus cannot always exist with respect to handicapped persons, for while much of the discrimination faced by them is based upon irrational prejudice, handicaps are also often related to ability, and thus to a criterion that is otherwise considered rational for the services they seek. ${ }^{20}$ Consequently, equal educational opportunity for handicapped children in public education may have to rest on a basis different from the commitment to other disadvantaged groups. The concept of parity accommodates the significant differences between the handicapped and nonhandicapped and describes what is possible and what is just in securing for the handicapped services for which they may not be eligible under what might otherwise seem to be fair and rational criteria.

I begin this article by describing the different ways courts have handled issues of cost arising under the EAHCA. I then examine the tensions between the structure and design of the EAHCA and the institutional context in which education is provided. These tensions arise from the EAHCA's creation of individualized rights, which must operate within an institution characterized by collective decisionmaking; from the focus in the EAHCA on the needs of an individual student without regard to his inability to compete in the meritbased system which the educational system is otherwise designed to promote; and from the imposition of national standards relating to the content of education which departs from a tradition of local and state decisionmaking in public education. I then describe the concept of program parity as a standard to mediate the tensions and resolve cost issues that arise under the EAHCA. This standard uses the existing framework for local educational decisionmaking to define state and local responsibility for educating the handicapped, and within that framework allows consideration of both the needs of the handicapped and the limitations of cost to which educational agencies are sensitive. It rejects a strict cost-benefit or efficiency analysis in allocating educational resources, emphasizing instead the premium that is appropriately put on the individual respect and integrity of handicapped children. It permits considerations of resource utility, however, as well as political judgments to influence decisions about the level of educational quality generally.

20. See Wegner, The Antidiscrimination Model Reconsidered: Ensuring Equal Opportunity Without Respect to Handicap Under Section 504 of the Rehabilitation Act of 1973, 69 CoRnell L. REv. 401, 429 (1984) [hereinafter cited as Antidiscrimination Model]. This point is explored further in section IV A, infra. 
II

\section{Judicial Responses to the Cost Issue}

Before examining further the concept of program parity, I will review the responses courts have made when cost is an issue in EAHCA litigation. These responses are inconsistent, reflecting the tensions which will be explored further in part III.

\section{A. Resolution One: Cost Not Relevant}

Some courts have insisted that the cost of a program sought by the parent of a handicapped child is not relevant to whether the child has a right to that program, and thus that cost is no defense to a failure to comply with the requirements of the EAHCA. ${ }^{21}$ This approach parallels the rejection of a broad cost defense in cases in which important constitutional rights are at stake, ${ }^{22}$ and in cases brought under antidiscrimination statutes designed to protect members of traditionally disadvantaged classes. ${ }^{23}$ As to claims based on specific legislation, this approach is particularly appealing when cost or administrative convenience was one of the underlying bases for the discrimination which the legislation sought to address. ${ }^{24}$

No constitutional basis has yet been established for the extension of special constitutional protection to handicapped children in public education. Handicap is not generally recognized as a suspect classification ${ }^{25}$ and the

21. E.g., Kruelle v. New Castle County School Dist., 642 F.2d 687, 695-96 (3d Cir. 1981); William S. v. Gill, 572 F. Supp. 509, 516 (N.D. Ill. 1983); Hines v. Pitt County Bd. of Educ., 497 F. Supp. 403, 408 (E.D.N.C. 1980); D.S. v. Board of Educ., 188 N.J. Super. 592, 609-10, 458 A.2d 129, $139-40$ (App. Div. 1983).

22. E.g., Memorial Hosp. v. Maricopa County, 415 U.S. 250, 263 (1974) ("[A] State may not protect the public fisc by drawing an invidious distinction between classes . . . so [the state] must do more than show that denying free medical care to new residents saves money."); e.g. Finney v. Arkansas Bd. of Correction, 505 F.2d 194, 201 (8th Cir. 1974) ("Lack of funds is not an acceptable excuse for unconstitutional conditions of incarceration"); Wyatt v. Aderholt, 503 F.2d 1305 (5th Cir. 1974) In Wyatt, a case involving involuntary commitment of the mentally ill, the court stated:

It goes without saying that state legislatures are ordinarily free to choose among various social services competing for . . . state funds. But that does not mean that a state legislature is free, for budgetary or any other reasons, to provide a social service in a manner which will result in the denial of individuals' constitutional rights.

Id. at 1314-15. see also Plyler v. Doe, 457 U.S. 202, 229 n.25 (1983) (incapacity to bear the costs of educating children of illegal aliens inadequate defense). See generally Wegner, supra note 20, at 447 48.

23. E.g., City of Los Angeles Dep't of Water \& Power v. Manhart, 435 U.S. 702, 716 -17 (1978) (sex-biased rates of contribution to city pension plan held a violation of Title VII despite showing of difference in projected costs of plan to different sexes); Smallwood v. United Air Lines, 661 F.2d 303, 307 (4th Cir. 1981), cert. denied, 456 U.S. 1007 (1982) (economic considerations are not a BFOQ under the Age Discrimination in Employment Act); see also Lora v. Board of Educ., 456 F. Supp. 1211 , 1292-93 (1978), vacated on other grounds and remanded, 623 F.2d 248 (1980) (city's budgetary problems no excuse for unconstitutional discrimination in classification of minority students).

24. See, e.g., Orzel v. City of Wauwatosa Fire Dep't, 697 F.2d 743, 755 (7th Cir. 1983), cert. denied, 104 S. Ct. 484 (1983) ("It is well established that economic factors cannot be the basis for a BFOQ since precisely those considerations were among the targets of the ADEA."); Smallwood v. United Airlines, 661 F.2d 303, 307 (4th Cir. 1981), cert. denied, 456 U.S. 1007 (1982).

25. Sherer v. Waier, 457 F. Supp. 1039, $1047-48$ (W.D. Mo. 1978); Levy v. City of New York, 38 N.Y.2d 653, 655, 345 N.E.2d 556, 558, 382 N.Y.S.2d 13, 15 (1976), appeal dismissed, 429 U.S. 805 
United States Supreme Court has not deemed education a fundamental right. ${ }^{26}$ Education for the handicapped, however, is the subject of remedial legislation intended to provide protection for a minority group which previously was significantly disadvantaged in public service. ${ }^{27}$ Moreover, one reason for traditional discrimination against the handicapped was (and remains) that the cost of serving them is too high. ${ }^{28}$

In some cases interpreting the EAHCA, the view that cost is not a relevant factor is expressed alongside an expansive definition of the underlying duties of school districts. ${ }^{29}$ Many courts take this approach without express discussion of the cost issue. ${ }^{30}$ Others reach this conclusion by reasoning that, unlike other types of legislation, the EAHCA does not mention cost as a limit on the

(1976); see also Doe v. Koger, 480 F. Supp. 225, 230 (N.D. Ind. 1979) (expressing serious doubts that handicapped students are a suspect class). But see Frederick L. v. Thomas, 408 F. Supp. 832, 836 (E.D. Pa. 1976) (handicapped persons are not a suspect class, but the middle-level equal protection standard applies); Fialkowski v. Shapp, 405 F. Supp. 946, 959 (E.D. Pa. 1975) (discrimination against handicapped persons should receive more than minimal judicial scrutiny); In re G.H., 218 N.W.2d 441,447 (N.D. 1974) ("G.H.'s terrible handicaps were . . . 'immutable characteristic[s]' . . to which the 'inherently suspect' classification would be applied.").

Several commentators have suggested that handicapped persons be afforded constitutional protection. See Burgdorf \& Burgdorf, A History of Unequal Treatment: The Qualifications of Handicapped Persons as a "Suspect Class" under the Equal Protection Clause, 15 SANTA Clara L. Rev. 855, 905-08 (1975) (arguing that handicapped should be a suspect classification); Krass, The Right to a Public Education for Handicapped Children: A Primer for the New Advocate, 1976 U. ILL. L.F. 1016, 1036-42 (also arguing for strict scrutiny for handicapped classification); Contemporary Studies Project, Special Education: The Struggle for Equal Educational Opportunity in Iowa, 62 IowA L. REv. 1283, 1354-59 (1977) (arguing for at least a "strict rationality" standard of review in handicapped cases).

26. San Antonio Indep. School Dist. v. Rodriguez, 411 U.S. 1, 37 (1973). But see Plyler v. Doe, 457 U.S. 202, 221-24 (1983) (discrimination in the education provided children of illegal immigrants must serve a substantial, rather than legitimate, state goal). State courts have by and large followed the lead of federal courts in holding that education is not a fundamental right. See Horton v. Meskill, 172 Conn. 615, 648-49, 376 A.2d 359, 373 (1977); Thompson v. Engelking, 96 Idaho 793, 805, 537 P.2d 635, 647 (1975). But see Serrano v. Priest, 487 P.2d 1241, 1244, 5 Cal. 3d 584, 589; 96 Cal. Rptr. 601, 604 (1971) (education is a fundamental right.)

27. See 20 U.S.C. $\$ 1400$ (b)(1)-(6), (c) (1982); S. ReP. No. 168, 94th Cong., 1st Sess. 9, reprinted in 1975 U.S. Code Cong. \& Ad. News 1425, 1433; H. Rep. No. 332, 94th Cong. 1st Sess. 11 (1975).

28. See 20 U.S.C. \$ 1400 (b)(7)-(9) (1982); S. REP. No. 168, 94th Cong., 1 st Sess. 7, reprinted in 1975 U.S. CODE Cong. \& AD. NEws 1425, 1431. ("In recent years [court] decisions . . have recognized the rights of handicapped children to an appropriate education. States have made an effort to comply; however, lack of financial resources have [sic] prevented the implementation of the various decisions . . ."); H. ReP. No. 332, 94th Cong., 1 st Sess. 26 (1975).

29. See, e.g., Kruelle v. New Castle County School Dist., 642 F.2d 687, 693 (3d Cir. 1981) (mentally retarded child with cerebral palsy who required continuous supervision entitled to more than 6 hour day program under EAHCA); T.G. v. Board of Educ., 576 F. Supp. 420, 423 (D.N.J. 1983) (same), affd, 738 F.2d 420, 425 (3d Cir. 1984); Hines v. Pitt County Bd. of Educ., 497 F. Supp. 403, 408 (E.D.N.C. 1980) (residential hospital placement for severely emotionally disturbed child held inappropriate because of the absence of an appropriate peer group, despite high cost of private school alternatives and confusion about availability of public placement); School Comm. v. Massachusetts, 1980-81 Educ. Handicapped L. Rep. 552:186 (Mass. Super. Ct. 1980) (benefits of continuity of psychiatric services justified placement with same psychiatrist despite existence of less expensive alterantive); In re "A" Family, 184 Mont. 145, 159-60, 602 P.2d 157, 166 (1979) (psychotherapy service in out-of-state residential placement a related service under the EAHCA); Adams Cent. School Dist. v. Deist, 214 Neb. 307, 314-18, 334 N.W.2d 775, 781-82 (retarded child entitled to residential placement even though it was not purely "educational"), modified, $215 \mathrm{Neb} .284,338$ N.W.2d 591, cert. denied, 104 S. Ct. 239 (1983).

30. E.g., T.G. v. Board of Educ., 576 F. Supp. 420 (D.N.J. 1983), (psychotherapy services), affd, 738 F.2d 420, 425 (3d Cir. 1984); Pires v. Pennsylvania Dep't of Educ., 78 Pa. Commw. 127, 467 A.2d 79 (1983) (residential placement outside of school district); Adams Cent. School Dist. v. Deist, 
duties it creates. ${ }^{31}$ One court, answering the argument that a placement could not be appropriate if its costs were inordinate, implied that while cost considerations motivated the drafters of the EAHCA to mandate an "appropriate" rather than the "most ideal" education, cost could not then be taken into consideration again in deciding what was appropriate. ${ }^{32}$ The point is also made that only states that have volunteered to participate in the EAHCA are bound by it. ${ }^{33}$ If economic hardship arises as a result, this must be addressed "through the normal political process, not through judicial emasculation of regulatory power." 34

The conclusion that cost is not a factor to consider may also be reached alongside a very narrow definition of the duties of school districts under the EAHCA. The decision of the United States Supreme Court in Board of Education $v$. Rowley ${ }^{35}$ may be viewed in this light. In holding that the defendant school district was required to provide only three hours of speech therapy weekly and an FM hearing aid to Amy Rowley to supplement the traditional educational program, the Court limited the scope of the EAHCA to the requirement that school districts provide each handicapped child "personalized instruction with sufficient support services to permit the child to benefit educationally from that instruction." 36 This requirement sets a low level of duty on the part of the school system, but seems to make the duty absolute, unqualified by any defense based on cost. ${ }^{37}$

214 Neb. 307, 334 N.W.2d 775 (residential placement), modified on other grounds, 215 Neb. 284, 338 N.W.2d 591, cert. denied, 104 S. Ct. 239 (1983).

31. E.g., Kruelle v. New Castle County School Dist., 642 F.2d 687, 695 (3d Cir. 1981) (“Under the Education Act, in contradistinction [to section 504 of the Rehabilitation Act], schools are required to provide a comprehensive range of services to accommodate a handicapped child's educational needs, regardless of financial and administrative burdens. . . ." (emphasis added); see also William S. v. Gill, 572 F. Supp. 509, 516 (N.D. Ill. 1983) (" $[T]$ he appropriateness of an education is a function not of cost but of the actual or potential educational benefits conferred.").

32. William S. v. Gill, 572 F. Supp. 509, 516 (N.D. Ill. 1983); see also Clevenger v. Oak Ridge School Bd., 744 F.2d 514, 517 (6th Cir. 1984).

33. Hines v. Pitt County Bd. of Educ., 497 F. Supp. 403, 408 (E.D.N.C. 1980). All states are now covered by the EAHCA. See supra note 4 .

34. D.S. v. Board of Educ., 188 N.J. Super. 592, 609, 458 A.2d 129, 140 (App. Div. 1983). Through the political process it is not determined whether, but rather how the necessary funds will be appropriated. See Kerr Center Parents Ass'n v. Charles, 572 F. Supp. 448, 459 (D. Or. 1983) (state legislature responsible for ensuring that special education is funded in state, either by providing funds itself, or by placing burdens on local school districts); School Comm. v. Bureau of Special Educ. Appeals, 389 Mass. 705, - 452 N.E.2d 476, 481 (1983) (state proposition "does not relieve a city or town from its educational responsibilities" to the handicapped) (unavailable in Massachusetts reporter at publication); see also Fallis v. Ambach, 710 F.2d 49, 50-53 (2d Cir. 1983) (absent showing of deprivation of free and appropriate education to handicapped children, EAHCA does not prevent state from reducing tuition rate at which public schools are required to reimburse private schools for education of handicapped children).

35. 458 U.S. 176 (1982).

36. Id. at 203.

37. This approach is admittedly difficult to distinguish from the approach of interpreting the substantive provisions of the EAHCA in a cost-sensitive manner. The latter approach is considered infra notes 44-49 and accompanying text. The Rowley decision is discussed further infra text accompanying notes $174-76$. 


\section{B. Resolution Two: Cost a Defense}

Courts have found a number of different ways to take cost into account under the EAHCA. These courts can be divided into those that consider the issue of cost as a potential defense to the failure to provide certain "appropriate" educational programs and those that make cost one factor to consider in interpreting the meaning of substantive provisions of the EAHCA.

There are only a handful of cases in which courts have rejected educational programs sought by parents of handicapped children expressly on grounds of cost. ${ }^{38}$ The rationale commonly given for this approach is that if a district were required to fund extremely expensive programs for some handicapped children it would not have enough money to educate other handicapped children properly. ${ }^{39}$ Courts have also been sensitive to the hardship placed on nonhandicapped children by diverting excessive expenditures from regular programs to programs for the handicapped. ${ }^{40}$

More often, courts taking cost into account have engaged in an explicit balancing process. In Pinkerton v. Moye, ${ }^{41}$ for example, the District Court balanced the individual needs of a learning-disabled child, whose mother sought the creation of a self-contained class in the school nearest the child's home (which was 19 miles away), against the realities of limited funding faced by the school district, for which it was less costly to send the child to a school

38. See, e.g., Rettig v. Kent City School Dist., 539 F. Supp. 768, 777 (N.D. Ohio 1981) (rejects cost-blind approach to EAHCA), affd in part, rev'd in part on other grounds, and remanded, $720 \mathrm{~F} .2 \mathrm{~d} 463$ (6th Cir. 1983); Bales v. Clarke, 523 F. Supp. 1366, 1371 (E.D. Va. 1981) (cost is always a factor in school placement decisions, even placement of nonhandicapped children); Pinkerton v. Moye, 509 F. Supp. 107, 112-13 (W.D. Va. 1981) (competing interests of parents and schools must be balanced). California state regulations specifically provide that cost be considered in determining a handicapped child's education placement. Cal. Educ. Code $\$$ 56505(i) (West Supp. 1984).

39. E.g., Rettig v. Kent City School Dist., 539 F. Supp. 768, 777 (N.D. Ohio 1981) (“a school cannot spend an exorbitant amount on one child at the expense of all its other handicapped children."), aff'd in part, rev'd in part on other grounds, and remanded, 720 F.2d 463 (6th Cir. 1983); Pinkerton v. Moye, 509 F. Supp. 107, 113 (W.D. Va. 1981) ("Excessive expenditures made to meet the needs of one handicapped child ultimately reduce the amount that can be spent to meet the needs of the other handicapped children." (footnote omitted)); Stacey G. v. Pasadena Indep. School Dist., 547 F. Supp. 61, 78 (S.D. Tex. 1982) ("Indeed, failure to consider these sometimes conflicting interests would ultimately work to circumvent Congress' intent to educate all handicapped children as best as practicable. Excessive expenditures made to meet the needs of one handicapped child may reduce the resources that can be spent to meet the needs of the other handicapped children."); Clevenger v. Oak Ridge School Bd., 573 F. Supp. 349, 350 (E.D. Tenn. 1983) ("[T]he Court should balance the needs of the handicapped child for a free and appropriate education with the need of the State to allocate scarce funds among as many handicapped children as possible."), rev'd and remanded, 744 F.2d 714 (6th Cir. 1984); Roncker v. Walter, 700 F.2d 1058, 1063 (6th Cir.), cert. denied, 104 S. Ct. 196 (1983). ("Cost is a proper factor to consider since excessive spending on one handicapped child deprives other handicapped children.”). Age v. Bullitt County Pub. Schools, 673 F.2d 141, 145 (6th Cir. 1982) ("[W] cannot say that the State has failed to reconcile satisfactorily [the boy's] need for a free, appropriate public education with the need for the State to allocate scarce funds among as many handicapped children as possible.").

40. See Bales v. Clarke, 523 F. Supp. at 1366, 1371 (E.D. Va. 1981); $c$. Note, Enforcing the Right, supra note 8, at 1123 (mainstreaming of handicapped children may diminish quality of education offered to other students in the class); Espino v. Besteiro, 520 F. Supp. 905, 912 (S.D. Tex. 1981) (air-conditioned classroom for benefit of handicapped child may raise complaints by nonhandicapped children who are not assigned to that classroom). But see infra note 73 .

41. 509 F. Supp. 107 (W.D. Va. 1981). 
six miles farther away. In concluding that the school district's placement of the child met the requirements of the EAHCA, the Court noted that this legislation "was not intended to totally supplant the state's prerogative in allocating its financial resources," and that "competing interests must be balanced to reach a reasonable accommodation." 42

Courts that have engaged in this balancing process have concluded in some cases that the concern of the school district for cost did not justify the denial of requested services. In one such case, the court balanced the needs of a multihandicapped child who could not regulate his body temperature against the fiscal considerations of the school district and held that the cost of a fully air-conditioned classroom, as compared with the single air-conditioned cubicle proposed by the district, was a reasonable burden in light of the amount of federal funds received by the district. ${ }^{43}$

\section{Resolution Three: Cost a Factor in Interpreting Substantive Provisions of Act}

Many courts that have considered cost have done so not by a separate balancing of the interests of the child and the school district but through a costsensitive interpretation of the substantive provisions of the EAHCA. A number of courts, for example, have considered the cost of various alternative educational programs and the financial well-being of the school district in deciding what educational program was "appropriate." In some cases courts justify this approach by distinguishing "appropriate" from "best," and iterating that the EAHCA does not guarantee the best possible education.44 Other courts more explicitly balance the needs of the child against the resources of the school system in determining what program is "appropriate." The First Circuit has taken this approach: "There can be little doubt . . . that in determining the 'appropriate' placement of the individual handicapped

42. Id. at 112 .

43. Espino v. Besteiro, 520 F. Supp. 905 (S.D. Tex. 1981); see also In re El Paso Indep. School Dist., 1981-82 Educ. Handicapped L. REP. (CRR) 503:260, :263 (Tex. SEA 1982) ("The administrative and financial burden on the district of providing [a crib for a severely handicapped child attending a full day program] is not undue."); Department of Educ. v. Katherine D., 727 F.2d 809, 813-14 (9th Cir. 1983) (although, because of budgetary constraints, school system required only to make efforts that are "within reason," in-school medical services were required to be furnished to child so that the child could attend regular public school); Tokarcik v. Forest Hills School Dist., 665 F.2d 443, 458 (3d Cir. 1981), cert. denied, 458 U.S. 1121 (1982); $c f$. Hurry v. Jones, 560 F. Supp. 500, 511 (D.R.I. 1983) (transportation services for physically handicapped child required under section 504 of the Rehabilitation Act since the services were "financially and administratively feasible" and would not impose an undue burden on the school district), affd in part, rev'd in part, 734 F.2d 879 (lst Cir. 1984).

44. See, e.g., Hessler v. State Bd. of Educ., 700 F.2d 134, 139 (4th Cir. 1983) (a state is not obligated to provide "the best education. . . that money can buy."); Age v. Bullitt County Pub. Schools, 673 F. 2d 141, 143-44 (6th Cir. 1982) (mere existence of a better program did not make the proposed program inappropriate under the Act); Bales v. Clarke, 523 F. Supp. 1366, 1371 (E.D. Va. 1981) (rejects the argument that the proper goal of an educational plan is "to achieve "maximum educational progress' through the 'best' education available" (quoting a witness in the case)); Darlene L. v. Illinois State Bd. of Educ., 568 F. Supp. 1340, 1345 (N.D. Ill. 1983); see also Board of Educ. v. Rowley, 458 U.S. 176, 198-204 (1982) (students need only be able to benefit from special instruction), and supra note 37. 
child, one must balance the important personal needs of the individual handicapped child, and the realities of limited public monies."45 One court justified this same balancing test on the ground that cost is also a factor in determining what is appropriate for nonhandicapped children. ${ }^{46}$

Still other courts have linked the question of what "related services" are required under the EAHCA to the question of their cost. Thus, children with spina bifida seeking clean intermittent catheterization (CIC) have been successful in persuading courts that this rather inexpensive service is a related service to which they are entitled, ${ }^{47}$ while many children seeking more expensive medical services, such as residential psychiatric services, have not. ${ }^{48}$ Finally, a few courts have limited the liability of school districts for costly residential placement in psychiatric facilities by excluding those expenses not attributable to traditional "educational" services. ${ }^{49}$

The range of responses courts interpreting the EAHCA have given to an issue as potentially critical as cost reflects a fundamental disagreement about the basic purpose and thrust of this legislation and its place within the broader goals and institutional framework of public education. The ad hoc manner in which the issue of cost has been approached to date has created confusion and inconsistency, encouraging on the one hand superficial compliance with the law, and on the other, overstated claims on behalf of some handicapped children.

One reason for the difficulty in resolving the issue of cost in decisionmaking under the EAHCA is that this legislation runs counter to a number of assumptions and traditions of public education in this country. How the EAHCA takes into account those aspects of public education has an important

45. Doe v. Anrig, 692 F.2d 800, 806 (1st Cir. 1982) (quoting from the opinion of the district court).

46. Bales v. Clarke, 523 F. Supp. 1366, 1371 (E.D. Va. 1981).

47. Irving Indep. School Dist. v. Tatro, 104 S. Ct. 3371, 3377-78 (1984) (approving the conclusion of the Secretary of the Department of Education, that the "medical services" exclusion to the "related services" provision "was designed to spare schools from an obligation to provide a service that might well prove unduly expensive and beyond the range of their competence" (footnote omitted)); Tokarcik v. Forest Hills School Dist., 665 F.2d 443 (3d Cir. 1981), cert. denied, 458 U.S. $1121(1982)$.

48. See, e.g., McKenzie v. Jefferson, 566 F. Supp. 404, $411-12$ (D.D.C. 1983) (distinguishing Irving Indep. School Dist. v. Tatro, 104 S. Ct. 3371 (1984), and Tokarcik v. Forest Hills School Dist., 665 F.2d 443 (3d Cir. 1981), cert. denied, 458 U.S. 1121 (1982), on grounds of cost, among other things); see also Stark, supra note 2, at 516-20 (describing practice in Connecticut of not treating psychotherapy as a "related service" for economic reasons, although most states treat psychological counseling as a related service). But see In re "A" Family, 184 Mont. 145, 160-61, 602 P.2d 157, 166 (1979) (psychotherapy at out-of-state residential placement is a related service); T.G. v. Board of Educ. 576 F. Supp. 420 (D.N.J. 1983) (out-patient psychotherapy is related service), affd, 738 F.2d 420, 425 (3d Cir. 1984).

49. E.g., Bill D., 1980-81 Educ. Handicapped L. Rep. (CRR) 502:259 (Conn. SEA 1981) (applying a state regulation); see Stark, supra note 2, at 506 . See generally Rothstein, Educational Rights of Severely and Profoundly Handicapped Children, 61 Neb. L. Rev. 586 (1982); Mooney \& Aronson, Solomon Revisited: Separating Educational and Other Than Educational Needs in Special Education Residential Placements, 14 ConN. L. REv. 531 (1982).

Cost could also be taken into account in the definition of the Act's "least restrictive alternative" provision. See Roncker v. Walter, 700 F.2d 1058, 1066 (6th Cir.) (Kennedy, J., dissenting), cert. denied, 104 S. Ct. 196 (1983). 
bearing on the success of its implementation. Three areas of tension between the EAHCA and the institutional context within which it must be implemented are explored in the next section.

\section{III}

\section{The EAHCA in the Context of the Institution of Public} Education: Three Tensions

The EAHCA requires that the handicapped child be provided an education that is based strictly on the needs of each individual child, and determined on a case-by-case basis, according to a federal standard of what is appropriate education. The law requires the EAHCA to be implemented in an institutional context in which decisions (both educational decisions and resource allocation decisions) are made collectively rather than on an individual basis; in which merit rather than needs per se are the organizing principle; and in which state and local government rather than the federal government control the context and quality of public education. These tensions are at the heart of the dilemma concerning the role of cost in educational decisionmaking under the EAHCA and must be explored further before any solution to this dilemma can be attempted.

\section{A. Individualized vs. Collective Decisionmaking}

1. Educational Programing Decisions. Perhaps the most remarkable feature of the EAHCA is its emphasis on the individual child. The EAHCA assumes that each handicapped child is unique. It requires that the level of performance of each handicapped child be individually identified; 50 that his or her needs be individually assessed ${ }^{51}$ "in all areas related to the suspected disability"; 52 that educational goals and plans for handicapped children be individually developed with "[a] statement of the specific special education and related services to be provided to the child" 53 and "[a]ppropriate objective criteria and evaluation procedures . . . for determining . . . whether the short term instructional objectives are being achieved";54 and that an "individualized education program" be developed for each child.55 The procedural mechanism for enforcing rights under the EAHCA maintains attention on the individual, affording parents the opportunity to have the child's educational program reviewed on a case-by-case basis, many times and at many different levels. ${ }^{56}$

50. 20 U.S.C. $\S 1412(2)(c)(1982) ; 34$ C.F.R. $\$ 300.128$ (1984).

51. 20 U.S.C. $\$ 1401(19)$ (1982); 34 C.F.R. $\$ 300.346$ (1984); see 20 U.S.C. $\$ 1413(\mathrm{a})(11)$

(1982); 34 C.F.R. $\S \S 300.128, .146$ (1984) (requiring evaluations of handicapped children).

52. 34 C.F.R. $\S 300.532(f)(1984)$

53. Id. $\S 300.346(\mathrm{c})$.

54. Id. $\S 300.346(\mathrm{e})$; accord 20 U.S.C. $\$ 1401(19)$ (1982). See generally 34 C.F.R. $\S \$ 300.341, .343$ (1984).

55. 20 U.S.C. $\S 1401(19)$ (1982); 34 C.F.R. $\$ \S 300.4, .341$ (1984).

56. See 20 U.S.C. $\$ 1415$ (b)(2) (1982) (hearing before impartial hearing officer); id. $\$ 1415$ (c) (appeal to state agency); id. $\$ 1415$ (e) (appeal in state or federal court). These hearing and appeal rights can apparently be exercised annually. Colley, supra note 11, at 150. 
At the hearing, the issue is limited to the needs and program of the individual child; concerns of the school system at large are not ordinarily relevant. ${ }^{57}$

This process of individual identification, needs assessment and programming contrasts sharply with the process of educational programming for other children. ${ }^{58}$ Establishment of public school programs precedes the identification of the needs of the individual students who will eventually be placed in those programs. Schools are organized into grades, perhaps into tracks within grades, and/or by courses that students are expected to take. These classifications conform to what is generally expected of students of that age, level of ability, and motivation. Grades and courses have standard curricula, determined in advance by state Boards of Education, local educational agencies, or in some cases teachers, according to what is perceived by members of the profession and policymakers to be appropriate for particular collective groups of children. ${ }^{59}$ The offering of common curriculum, indeed, has long been considered an important aspect of educational opportunity in American education. Standardization is to ensure that children are given educations that will enable them to achieve regardless of background. ${ }^{60}$ Even the development of tracks appropriate to different types of occupational paths and electives to accommodate different interests and career goals ${ }^{61}$ manifest planning by group rather than by individual.

Nonhandicapped students are often assessed individually according to some scale of individual performance, such as grades or scores on standardized tests. These evaluations are only gross placement devices, however, determining such questions as whether the student should progress to the next grade, what level of courses the student should take, or what sort of recommendation the student will receive for college admission or employment. Schools do not use them to tailor an individual program for a child. Students in their respective classrooms are expected to master the curriculum and are evaluated according to their success in doing so. In teaching the curriculum, the teacher will sometimes tailor the teaching technique or pace according to individuals within that class; nevertheless, the goals for the class and the individuals within that class are standard ones, and do not vary significantly

57. See 34 C.F.R. $\S \S 300.504, .506$ (1984) (Parent or agency may initiate hearing on any matters discussed in $\$ 300.504$, which deals with individual placements.) See also discussion of Poe v. Durham County Schools, No. 82-2566 (N.C. Super. Ct. 1982), in Comment, Age Appropriateness as a Factor in Educational Placement Decisions, LAW \& Contemp. Probs., Winter 1985, at 94-98 (hearing officer refused to hear evidence relating to other similarly situated children). For a brief discussion of whether the class action vehicle is available under the EAHCA, see Note, Enforcing the Right, supra note 8 , at 1113 n.62, $1115-18$.

58. See generally P. Hill \& D. Madey, Educational Policymaking Through the Civil Justice System (1982); Moore, Walker \& Holland, supra note 3.

59. D. Tyack, The One Best System 45-47 (1974); P. Hull \& D. Madey, supra note 58, at 1.

60. Coleman, The Concept of Equal Educational Opportunity, 38 HARv. Educ. Rev. 7 (1968), reprinted in Equal Educational Opportunity 13 (1969); Resnick \& Resnick, Improving Educational Standards in American Schools, 65 Phi Delta Kappan 178, 178 (1983).

61. Resnick \& Resnick, supra note 60, at 178. 
according to the needs and abilities of each child.62 Moreover, children (or their parents) who disagree with curricular, methodological or structural features of the system have no recourse outside whatever informal pressure they can exert; they have no legally enforceable rights to any particular type of education nor even to a right to equality in education. If dissatisfied, their only recourse is through the political, not the legal, process. ${ }^{63}$

2. Resource Allocation Decisions. The contrast between the individualized and nonindividualized approaches apparent in educational decisionmaking for handicapped and nonhandicapped children persists with respect to resource allocation decisions. Under the EAHCA, individual needs are to be identified and educational programs provided that will address those needs appropriately. This legislation attends only to the individual needs, and does not acknowledge any clash between the needs and programs of the individual and those of others. By taking no direct account of resource limitations or qualifications on the duty to provide what is appropriate, the EAHCA implies that resources must be made available to meet the individual needs of the handicapped child. ${ }^{64}$

In contrast, the framework within which competing claims for limited public school resources are usually made is one of collective decisionmaking. ${ }^{65}$ Both the allocation of resources to public schools and the division of resources between different school programs take place in a process that is political rather than compulsory. ${ }^{66}$ The availability of funds determines the level of a school budget, ${ }^{67}$ and negotiations determine amounts allocated for certain needs within that budget. Through this process, the perceived needs and interests of constituent groups are evaluated, asserted, and debated. Decisions are made, usually after consideration of many alternatives. Claims or programs thought to be more worthy are honored over others less valued.

62. Glaser, Adapting to Individual Differences, in ANNuAl Editions Education 80/81, at 181,182 $83(1980)$.

63. See San Antonio Indep. School Dist. v. Rodriguez, 411 U.S. 1, 37 (1973); Lujan v. Colorado State Bd. of Educ. 649 P.2d 1005, 1018 (Colo. 1982); cf. Dandridge v. Williams, 397 U.S. 471,487 (1970) (courts should not second-guess state officials allocating welfare funds). But see, e.g., Pauley v. Kelly, 255 S.E.2d 859, 878 (W.Va. 1979) (individual students stated claim of action against state for discriminating school finance system); Horton v. Meskill, 172 Conn. 615, 648-49, 376 A.2d 359, 374 (1977) ("[E]lementary and secondary education is a fundamental right . . . [and] pupils in the public schools are entitled to equal enjoyment of that right . . . .").

64. See supra notes 31-32 and accompanying text.

65. The EAHCA contrasts even with the process through which other special groups, such as the educationally disadvantaged, compete for limited federal funds which are distributed by local administrators to only a fraction of eligible beneficiaries. In these kinds of programs, program eligibility is not equivalent to entitlement; it is only a threshold factor, allowing one to compete against others for limited resources. See P. HrLl \& D. MADEY, supra note 58, at 2; see, e.g., 20 U.S.C. \$2732 (1982); see also infra note 70 .

66. See Lujan v. Colorado State Bd. of Educ., 649 P.2d 1005, 1022-23 (Colo. 1982) (members of school board, controlled by voters, determine how much money to raise for schools and how that money will be spent); Board of Educ. v. Nyquist, 57 N.Y.2d 27, 44-46, 439 N.E.2d 359, 366-67, 453 N.Y.S.2d 643, 651-52 (1982) (identifying the different levels of government involved in funding schools), appeal dismissed, 459 U.S. 1139 (1983).

67. Wise, Educational Adequacy: A Concept in Search of Meaning, 8 J. Educ. Fin. 300, 314 (1983). 
In responding to the selective creation of enforceable rights for the handicapped, school districts initially obtained extra appropriations for special education and additional services for handicapped children. ${ }^{68}$ By the late 1970's, however, extra appropriations were more problematic and "school systems maintained the quality of special education services by diverting funds from other categorical grant programs." 69 Because other special interest groups, especially the poor, did not have individual rights enforceable in the judicial system, ${ }^{70}$ these other groups were significantly disadvantaged with respect to the handicapped. ${ }^{71}$ Upper and middle class parents were most able to assert their claims. ${ }^{72}$ And it was charged that funds were pulled from programs otherwise intended for nonhandicapped children in order to serve the handicapped. ${ }^{73}$

The tension between the individualized decisionmaking required under the EAHCA and the institutional context within which decisions are usually made on the basis of collective considerations is destabilizing. On the one hand, some children are selected for a track that entitles them to special treatment and immunizes them from restraints, including resource restraints, to which others are subject. This seems grossly unfair to other children, who may have complaints about the quality of their own education. In response to this perceived unfairness and to genuine resource limitations, school officials (either intentionally or unintentionally) may subvert educational programming for handicapped children; they may, for example, limit their consideration in placement decisions to programs that are already available in a school district rather than to those programs and others that might be made available. ${ }^{74}$

68. P. HiLl \& D. MADEY, supra note 58, at 24.

69. Id. at 25 .

70. Many disadvantaged groups are protected, of course, by nondiscrimination statutes. See, e.g., section 601 of the Civil Rights Act of 1964, 42 U.S.C. $\$ 2000$ (d) (1982) (Title VI); Section 504 of the Rehabilitation Act of 1973, 29 U.S.C. $\$ 794$ (1982); Sections $901-05,907$ of the 1972 Education Amendments, 20 U.S.C. $\S \S 1681-86$ (1982) (Title IX). With the possible exception of Title VI, however, these statutes generally have not been interpreted to require broad affirmative steps requiring the expenditure of significant funds. See, e.g., Southeastern Community College v. Davis, 442 U.S. 397 (1979) (interpreting section 504 of the Rehabilitation Act of 1973). Often any relief at all is dependent upon a showing of discriminatory intent. See, e.g., Guardians Ass'n v. Civil Serv. Comm'n, $103 \mathrm{~S}$. Ct. 3221 (1983) (compensating relief in a Title VI action requires proof of a discriminatory intent). Even Lau v. Nichols, 414 U.S. 563 (1974), did not clearly give a cause of action to an individual child for some educational benefit. See Levin, Equal Educational Opportunity for Special Pupil Populations and the Federal Role, 85 W. VA. L. Rev. 159, 178 (1983). See infra notes 123-28 and accompanying text.

71. P. Hill \& D. MADEY, supra note 58, at 25.

72. Neal \& Kirp, The Allure of Legalization Reconsidered: The Case of Special Education, LAW \& CoNTEMP. Probs., Winter 1985, at 63, 78 .

73. Id. at 79. See Note, Enforcing the Right, supra note 8, at 1123; Stark, supra note 2, at 493. See also supra note 40 . One research team has concluded that this diversion has not actually occurred. See P. Hill \& D. MadeY, supra note 58, at 25; see also cases cited supra note 40; M. KNAPP, M. STEARNS, B. Turnbull, J. David \& S. Peterson, Cumulative Effects of Federal Education Policies on Schools and Districts, Summary Report of a Congressionally Mandated Study 6 (1983) (no substantial effects of federal programs on nontarget students).

74. See Note, Board of Education v. Rowley, supra note 8, at 279, 286-87 (1983); Large, Special Problems of the Deaf Under the Education for All Handicapped Children Act of 1975, 58 WASH. U.L.Q. 213 , 256 (1980); Miller \& Miller, The Handicapped Child's Civil Right as it Relates to the "Least Restrictive Environment" and Appropriate Mainstreaming, 54 IND. L.J. 1, 5 (1978); Note, Enforcing the Right, supra note 8 , 
The law might respond to this tension either by making the process for educational programming decisions for handicapped children conform to the collective, largely political process used for nonhandicapped children, or by requiring individual assessments and programming for every child. Neither of these alternatives, however, is satisfactory. Folding the handicapped into the collective process of decisionmaking that works for the nonhandicapped led to the disregard of handicapped children and to their segregation in public education prior to passage of the EAHCA. The political weakness of the handicapped minority at the local district level, ${ }^{75}$ prejudice and discomfort toward the handicapped, ${ }^{76}$ ignorance about the capacity and value of the handicapped, ${ }^{77}$ disagreements among professionals, ${ }^{78}$ overburdened teachers and administrators, ${ }^{79}$ and funding shortages ${ }^{80}$ together continue to make fair treatment of the handicapped unlikely absent a requirement of individualized

at 1109-10. This charge was confirmed in one study. See David \& Greene, Organizational Barriers to Full Implementation of PL 94-142, in Special Education Policies, Their History, Implementation, AND FinANCE 1 15, 125-26, 132 (1983); see also Weatherly \& Lipsky, Street-Level Bureaucrats and Institutional Innovation: Implementing Special Education Reform, 47 HaRv. Educ. Rev. 171, 187 (1977) (similar findings in study of implementation of Massachusetts special education law requiring individual assessments).

Courts that have addressed this practice have generally rejected it. See, e.g., Georgia Ass'n of Retarded Citizens v. McDaniel, 716 F.2d 1565, 1576-77 (1 l th Cir. 1983) (state cannot ignore needs of handicapped individuals with a policy limiting educational programs to 180 days per year), vacated on other grounds, 104 S. Ct. 3581 (1984); Crawford v. Pittman, 708 F.2d 1028, 1033-35 (5th Cir. 1983) (same). See also Note, Defining an "Appropriate Education," supra note 8, at 110. But cf. Grkman v. Scanlon, 563 F. Supp. 793, 797 (W.D. Pa. 1983) (case remanded to determine most appropriate available alternative); Tilton v. Jefferson County Bd. of Educ., 705 F.2d 800 (6th Cir. 1983) (closing of facility for budgetary reasons not a change of placement triggering due process procedures of the Act), cert. denied, 104 S. Ct. 998 (1984).

75. See, e.g., Garrity v. Gallen, 522 F. Supp. 171, 224 (D.N.H. 1981) (“[w]hether out of timidity in the face of this powerful local voice, out of deference to the local taxpayers who are primarily footing the bill for education in the state, or out of sheer abdication of responsibility, the State Board of Education has failed to fulfill its responsibility" under the Act.) This is not to say, however, that the handicapped, particularly in recent years and at the national level, have been powerless. See Neal \& Kirp, supra note 72, at 68-70; Finn, Advocating for the Most Misunderstood Minority: Securing Compliance with Special Education Laws, 14 Suffolk U.L. REv. 505, 513 (1980). For a chronicle of the move from political powerlessness to effective advocacy, see Tweedie, The Politics of Legalization in Special Education Reform, in Special Education Policies 48 (1983).

76. See Note, Enforcing the Right, supra note 8, at 1123, n.131; Eisenberg, Disability as Stigma in Disabled People as Second-Class Citizens 3 (1982); Griggins, The Disabled Face a Schizophrenic Society, in Disabled People as Second-Class Citrizens 30 (1982); see also infra note 138.

77. See tenBroek \& Matson, The Disabled and the Law of Welfare, 54 Calif. L. Rev. 809, 809-10 (1966); Blakely, Judicial and Legislative Attitudes Toward the Right to an Equal Education for the Handicapped, 40 Онго ST. L.J. 603, 603-05 (1979); Note, A Modern Wilderness-The Law of Education for the Handicapped, 34 Mercer L. Rev. 1045, 1045-1048 (1983).

78. See, e.g., Age v. Bullitt County Pub. Schools, 673 F.2d 141 (6th Cir. 1982) (dispute over what method of educating the deaf is superior); Doe v. Lawson, 579 F. Supp. 1314, 1316-19 (D. Mass. 1984) (dispute over techniques of educating a severely retarded child); In re Marin County Office of Educ., 1982-83 Educ. HANDiCAPPEd L. REP. (CRR) 504:162 (Cal. SEA 1982) (dispute over method of vocational instruction for handicapped student); Johnston v. Ann Arbor Pub. Schools, 569 F. Supp. 1502 (E.D. Mich. 1983) (dispute over feasibility of mainstreaming). See also Note, Enforcing the Right, supra note 8, at 1109; Kirp, Buss \& Kuriloff, Legal Reform of Special Education: Empirical Studies and Procedural Proposals, 62 CALIF. L. REv. 40, 47 (1974); Halligan, The Function of Schools, the Status of Teachers, and the Claims of the Handicapped: An Inquiry Into Special Education Malpractice, 45 Mo. L. REv. 667, 681 (1980); Large, supra note 74, at 229-38.

79. See Note, Enforcing the Right, supra note 8, at 1110.

80. See generally Stark, supra note 2; see also infra note 118. 
attention. When children are assessed according to standardized measurements used to put the handicapped into categories with pre-formulated programs, the exceptional needs of the handicapped are not likely to be understood, and responsibility for meeting those needs is not likely to be taken as seriously as for those of the nonhandicapped.

Individualized needs assessment and programming for every nonhandicapped child is also unrealistic. Although the EAHCA has led to a practice of individualizing educational programs that may spill over into procedures for nonhandicapped children, it is difficult to imagine public education operating under its current resource restraints while engaging in the kind of individualized procedures for all children that are now required only for the 10 to 12 percent of children who are handicapped. ${ }^{81}$

I will return to this tension between the mandate for individualized programming under the EAHCA and the practice of collective decisionmaking in public education after I have examined two other tensions also underlying the EAHCA.

\section{B. Need vs. Merit}

The focus of the EAHCA is on the needs of the handicapped child. This focus creates a certain dissonance with the merit principle upon which the public education system is largely based. Under the merit principle, individuals "should be enabled to attain some particular social good on the basis of their natural abilities and/or actual achievement and not on the basis of arbitrary or ascriptive factors." 82 This principle is a basic component of liberal political philosophy and draws support from instrumental judgments about what makes for an efficient society. A competing, but equally basic, liberal tenet stresses needs rather than merit: individuals should be afforded roughly equal chances to achieve their desired goals. ${ }^{83}$ These two concepts are pursued simultaneously through public education: schools meet the needs of children by developing their talent so that they may achieve. Education eliminates artificial impediments unrelated to merit or true natural abilities ${ }^{84}$ so that children may have the opportunity to display and develop their talents

81. Moore, Walker \& Holland, supra note 3, at 11.

82. Joseph, supra note 18, at 394; see Frankel, Equality of Opportunity, 81 EtHIcs 191, 192 (1971) ("democrats and antidemocrats, socialists and adherents of free enterprise, have all apparently been able to say that they believe in at least this much-that individuals ought to have a chance to go as far as their talents permit, and that it is the mark of a good society that its best people rise to the top").

83. This concept is usually referred to as equal opportunity; one writer expresses it perhaps more precisely as that of "equality of life chances." J. Fishin, Justice, Equal. OPPORTUNiTY, AND THE FAMILY 20, 32 (1983). Equal opportunity to participate fully in the meritocracy is often viewed as a primary goal of nondiscrimination legislation. See, e.g., Blumstein, Defining and Proving Race Discrimination: Perspectives on the Purpose vs. Results Approach from the Voting Rights Act, 69 VA. L. REv. 633, 63839 (1983) ("race-based discrimination violates the societal goal of a fair, individualized, and meritocratic procedural framework for decisionmaking").

84. See J. Fishkin, supra note 83, at 32 (1983) (defining as arbitrary any factor which does not "[predict] the development of qualifications to a high degree among children who have been subjected to equal developmental conditions."'). 
and reach their rightful level in society based on merit. ${ }^{85}$ The education system uses merit as the measurement of success and the basis for classification and advancement. In addition, the system seeks to make up for deficiencies of talent by affording extra help to those who need it most. ${ }^{86}$

Factors relating to many handicaps-physical ability, physical self-sufficiency, the ability to process letter combinations accurately, personality, discipline - may be seen either as components of talent to be used to select the child's rightful place in the meritocracy, or as impediments which should be overcome by education so that the child's achievements will match the achievements of children who are alike in ability except for the handicapping condition. When talent is defined broadly, the realm within which education seeks to modify or correct the barriers to achievement that the child brings with him to school is narrow. A restrictive interpretation of talent, on the other hand, leaves a broad realm within which education seeks to affect factors that influence educational success including, ultimately, academic talent itself. ${ }^{87}$

Under a merit system, talent may provide a valid criterion for distributing educational resources. The most talented may require the most extensive and advanced educational services as the meritocracy prepares them to make the maximum contribution to society. This will justify in some cases the distribution of resources in proportion to merit. ${ }^{88}$ Moreover, a focus on merit nar-

85. See Bell, On Meritocracy and Equality, 29 PuB. INTERest 29, $41-42$ (1972); Wilson, Social Class and Equal Educational Opportunity, 38 HARV. ED. REv. 77, 79-80 (1968), reprinted in EQUAL EDUCATIONAL Opportunity 80, $82-83$ (1969); Yudof, Equal Educational Opportunity and the Courts, 51 TEX. L. REV. 411,418 (1973); see also Plyler v. Doe, 457 U.S. 202, 221-22, (1982) ("In addition to the pivotal role of education in sustaining our . . . heritage, denial of education to some isolated group of children poses an affront to one of the goals of the Equal Protection Clause: the abolition of governmental barriers presenting unreasonable obstacles to advancement on the basis of individual merit."); Brown v. Board of Educ., 347 U.S. 483, 493 (1954) (importance of education offered on equal terms to all to enable children to succeed).

86. See, e.g., Education Consolidation and Improvement Act of 1981, 20 U.S.C. $\$ \S 3801-3876$ (1982) (establishing federal program of financial assistance for education of disadvantaged children).

87. See Wilson, supra note 85, at 79, reprinted in EQUal EduCATIONAL OPPORTUNITY at 82 . Wilson elaborates as follows:

The traditional liberal view of equality of opportunity which motivated the extension of public elementary and secondary education in this country would, as far as possible, remove legal and economic handicaps to the acquisition of education by intelligent and industrious youths whose parents sought their social advancement. The more radical conception calls for the provision of experiences which generate intelligence and arouse interest even where the influence of home and neighborhood may be impoverished or hostile.

Id. (footnote omitted). Charles Frankel describes as dichotomous the "educational" and "meritocratic" approaches to equal opportunity. Frankel, supra note 82, at 203-04; see also D. RAE, EQUALITIES 65-66 (1981) (comparing "prospect-regarding" equal opportunity, defined as an equalized probability that persons will attain the same goal, to "means-regarding" equal opportunity, which equalizes external circumstances relevant to particular goals, but not those qualities about peoplewit, speed, strength-that may result in "legitimately" unequal prospects of success); Fishkin, supra note 83 , at $34-35$.

The attention given to ensuring that educational assessments do not result in a disproportionate number of minority children in special education programs illustrates the perception that factors of handicap should be kept separate from sociocultural factors. See generally Placing ChILDREN IN SPEcial Education: A Strategy for Equity (1982) [hereinafter cited as Placing Children in SPEcial Education].

88. Arthur Wise's "competition" definition of equality of educational opportunity would pro- 
rows the range of goals that are appropriate for an educational system to pursue. If such factors as the level of ambition, attitude toward learning, extent of curiosity, and quality of personal tastes are all factored into the definition of talent, a school may remain faithful to a merit-based vision by setting goals for the child based in part on these factors, rather than by trying to modify them.

In requiring that educational services be made available to handicapped children entirely on the basis of need, the EAHCA upsets the rough balance between need and merit in public education. Under the EAHCA, the role of merit and need is reversed. Instead of identifying and meeting needs that must be met for a child to be able to find his rightful place in the educational system (and in society) based on merit, ability is assessed in order to determine the child's due in the educational system based upon need. Indeed, insofar as the EAHCA places a priority upon meeting the needs of severely handicapped children, ${ }^{89}$ for whom the cost of education is extremely high, ${ }^{90}$ it requires that resources be set apart for the handicapped roughly in inverse proportion to their "merit."

The need-based focus of the EAHCA is essential, for without it, the position of the handicapped with respect to claims for scarce resources would be extremely weak. The compensatory assistance to which a person disadvantaged by race or social class is entitled under the merit system in order that he have an opportunity to reach his true place in the hierarchy or obtain his "fair" share of society's rewards based on merit, would elude the handicapped person whose disadvantage relates directly to his innate abilities. Without coming to terms with the contrary inclinations of the merit-based system of public education, however, this focus will be difficult to maintain.

\section{Federal vs. Local and State Decisionmaking: The Federalism Tension}

The EAHCA establishes uniform federal procedures and standards for education of the handicapped. This uniformity is in tension with a longstanding tradition in this country of state and local control over public education.

Many important procedural and substantive issues are preempted by the EAHCA. A local school district may not, for example, decide to serve children with learning disabilities before tackling the more difficult job of providing educational services to severely retarded children, ${ }^{91}$ or to eliminate the role of parents in the planning process, ${ }^{92}$ or to educate all handicapped

mote this pattern. A. Wise, Rich Schools, Poor Schools 153-54 (1968). Because the removal of artificial barriers can be costly, however, and because in some respects the talented will not need substantial resources to find their rightful place in society, this merit-based allocation method will not always best promote a meritocratic system.

89. See 20 U.S.C. $\$ 1412(3)$ (1982); 34 C.F.R. $\$ \S 300.320-.321$ (1984).

90. See KaKalik, supra note 2 , at $332-36$ (comparing $\$ 5926$ cost of educating severely retarded child with $\$ 3795$ for educable retarded child and $\$ 2253$ for speech-impaired child).

91. See 20 U.S.C. $\$ 1412(3)$ (1982); 34 C.F.R. $\$ \S 300.320-.321$ (1984).

92. See 20 U.S.C. $\$ 1415$ (b)(1) (1982); 34 C.F.R. $\$ \S 300.343-.345$ (1984). 


\section{children in segregated classrooms..$^{93}$}

The EAHCA has been described "as a model of "cooperative federalism," "94 but if it is, it is a different model than that which has characterized the respective roles of local, state, and federal governments in public education in recent decades. ${ }^{95}$ In the earliest days of public education in this country, operation and control over schools was left entirely up to local government and parents. In the nineteenth century, small, local school districts were consolidated, usually by towns, and states gradually assumed some of the control over education. ${ }^{96}$ Today, the states rather than the federal or local governments are considered ultimately responsible for public education, ${ }^{97}$ but consistent with the strong tradition of local control over education, ${ }^{98}$ many responsibilities are delegated to local educational agencies. ${ }^{99}$ Thus, states commonly issue rules and regulations pertaining to teacher cert-

93. See 20 U.S.C. $\S \S 1412(5)(B), 1414$ (a)(1)(C)(iv) (1982); 34 C.F.R. $\S \S 300.550-.556$ (1984).

These requirements of the EAHCA also coopt decisionmaking relating to the allocation of resources needed to satisfy them. See supra notes 64-73 and accompanying text.

94. Georgia Ass'n of Retarded Citizens v. McDaniel, 716 F.2d 1565, 1569 (11th Cir. 1983), vacated on other grounds, $104 \mathrm{~S}$. Ct. 3581 (1984).

95. This shift to a certain extent was anticipated in the Senate debates over the EAHCA. See 121 Conc. REC. 19,498 (1975) ("this measure will greatly change the Federal role in the education of handicapped children in this Nation.") (remarks of Sen. Dole). Senator Dole's remarks, however, were directed at the financial burdens the legislation would create for the federal (and state) governments, not the impact on state sovereignty over the educational system. $I d$.

96. See Kaestle \& Smith, The Federal Role in Elementary and Secondary Education, 1940-1980, 52 Harv. Educ. Rev. 384, 384 (1982); M. Milstein, Impact and Response: Federal Aid and State Educational Agencies 3-4 (1976); see also Andrus v. Hill, 73 Idaho 196, 200, 249 P.2d 205, 207 (1952) ("Traditionally, not only in Idaho but throughout most of the states of the Union, the legislature has left the establishment, control and management of the school to the parents and taxpayers in the community which it serves."); Board of Educ. v. Nyquist, 57 N.Y.2d 27, 46, 439 N.E.2d 359, 367,453 N.Y.S.2d 643, 652 (1982) ("For all of the nearly two centuries that New York has had public schools, it has utilized a statutory system whereby citizens at the local level . . . have made the basic decisions on . . . operating their own schools." (quoting the amici curiae brief of 85 public school districts)), appeal dismissed, 459 U.S. 1138 (1983).

97. See 121 Cong. Rec. 19,498 (1975) (statement of Sen, Dole) ("Historically, the States have had the primary responsibility for the education of children at the elementary and secondary level.").

98. See Milliken v. Bradley, 418 U.S. 717, 741 (1975) ("No single tradition in public education is more deeply rooted than local control over the operation of public schools. . . ."); Washington $v$. Seattle School Dist., 458 U.S. 457, $477-49$ (1982) (describing the duties of local school boards); San Antonio Indep. School Dist. v. Rodriguez, 411 U.S. 1, $47-49$ (1973) (tracing the history of local control over education in Texas); Martinez v. Bynum, 461 U.S. 321,329 (1983) (education "is one of the most important functions of local government"); Brown v. Board of Educ., 347 U.S. 483,493 (1954) ("Today, education is perhaps the most important function of state and local governments."). See also Coleman, Rawls, Nozick, and Educational Equality, 43 Pub. INTEREst 121, 123 (1976).

99. See Robinson v. Cahill, 69 N.J. 449, 458, 355 A.2d 129, 133 (1976) (running the schools has been largely delegated to local governments); Thompson v. Engelking, 96 Idaho 793, 803, 537 P.2d 635,645 (1975) (local governments control these schools (quoting Andrus v. Hill, 73 Idaho 196, 200, 249 P.2d 205, 207 (1952)); Campbell v. Board of Educ., 193 Conn. 93, 96-97, 475 A.2d 289, 291 (1984) (state constitution requires the state to provide public education, but this obligation has been delegated to local governments); Levin, Federal Grants and Educational Equity, 52 Harv. Enuc. REv. 444, 445 (1982).

Only the State of Hawaii has not delegated power over education to local school districts. Hawall Rev. STat. $\$ 27-1(1)$ (1976); Kaden, supra note 18, at 1210.

For a brief history of the relationship between state and local government in the control of educa. ion, see M. Milstein, supra note 96, at 3-6; Kaestle \& Smith, supra note 96, at 384-87; see also 1cLaughlin, States and the New Federalism, 52 HaRv. EDUC. Rev. 564 (1982) (describing variations in tate relationships with both local and federal educational agencies). 
ification, ${ }^{100}$ textbooks ${ }^{101}$ and curriculum matters, ${ }^{102}$ testing, ${ }^{103}$ length of school year ${ }^{104}$ and attendance guidelines, ${ }^{105}$ but local educational agencies typically exercise considerable discretion in these areas, as well as primary control over such matters as local school finance, ${ }^{106}$ discipline, ${ }^{107}$ educational methodology, ${ }^{108}$ extracurricular programs, ${ }^{109}$ health and safety standards, ${ }^{110}$ and other internal school matters. ${ }^{111}$

Earlier federal limits imposed on state and local control over education related largely to access, rather than to the substance of educational programs. The federal Constitution has been interpreted to forbid states from interfering with certain prerogatives of parents with respect to their children, but not to preclude states from structuring an educational system as they wish. Thus, parents may be able to insist upon private alternatives to public education ${ }^{112}$ or upon the elimination of unconstitutional limitations on what is available in public schools. ${ }^{13}$ Ordinarily, however, parents may not hinder the school in fulfilling what the school sees as its educational mission.114

100. See, e.g., Cal. Educ. Code $\$ 44330$ (West 1978); Md. Educ. Code Ann. $\S 2-303$ (g) (1978); Mich. Сomp. Laws Ann. $\S \S 380.1531-1535$ (West Supp. 1984-85); N.J. Stat. ANN. $\S \S 18 A: 6-38,: 26-$ 1.2 (West 1968 \& Supp. 1984-85).

101. See, e.g., Cal. Educ. Code $\$ \S 60200,60401$ (West 1978 \& Supp. 1984); N.J. STat. ANN. § 18A:34-1 (West 1968); N.C. Gen. Stat. §§ 115C-85 to-102 (1983); $c f$. Md. Educ. Code Ann. § 7 106 (1978); Mich. CoMp. Laws ANN. $\$ \$ 380.1421-1437$ (West Supp. 1984-85).

102. See, e.g., Cal. Educ. Code $\$ \S 51202-51260$ (West $1978 \&$ Supp. 1984); Ill. AnN. Stat. ch. $122, \S \S 27-1$ to -22 (Smith-Hurd 1962 \& Supp. 1984-85); Мich. Comp. LAws AnN. § $\$ 380.1151$ .1174 (West Supp. 1984-85); N.J. Stat. AnN. §§ 18A:35-1 to -4.8 (West 1968 \& Supp. 1984-85); cf. Mo. Educ. Code AnN. § 4-110 (1978 \& Supp. 1983).

103. See, e.g., Fla. Stat. Ann. $\$ 229.57$ (West 1977 \& Supp. 1984); N.C. Gen. Stat. \$ $\$ 15 C-175$ to $-184(1983)$.

104. See, e.g., Cal. Educ. Code $\$ \S 37200-37707$ (West 1978 \& Supp. 1984); Mo. Educ. Code Ann. § 7-103 (1978 \& Supp. 1983); Мich. Comp. Laws AnN. § 380.1284 (West Supp. 1984-85); N.J. StAT. ANN. §§ 18A:36-1, :36-2 (West 1968 \& Supp. 1984-85)

105. See, e.g., Ill. AnN. Stat. ch.122, \&\$ 26-1, -2 (Smith-Hurd 1962 \& Supp. 1984-85); MD. Educ. Code Ann. § 7-301 (1978 \& Supp. 1983); Мıсн. Comp. Laws Ann. $\$ \$ 380.1541, .1561$ (West Supp. 1984-85).

106. See, e.g., Fla. Stat. Ann. § 230.23(10) (West 1977 \& Supp. 1984); Ill. Ann. Stat. ch. 122, $\S \S 17-1,-2$ (Smith-Hurd 1962 \& Supp. 1984-85); Mich. Comp. Laws AnN. $\S 380.1211$-.1212 (West Supp. 1984-85).

107. See, e.g., Fla. Stat. Ann. $\$ 230.23(6)$ (c)-(d) (West $1977 \&$ Supp. 1984); Md. Educ. Code Ann. § 7-304 (1978 \& Supp. 1983); Mich. Comp. Laws AnN. $\S$ 380.1311-.1312 (West Supp. 198485).

108. See, e.g., Fla. Stat. Ann. § 230.23(7) (West 1977 \& Supp. 1984); Mich. Comp. Laws Ann. $\S 380.1282$ (West Supp. 1984-85); N.C. GeN. Stat. § 115C-47(12) (1983).

109. See, e.g., Mich. Comp. Laws Ann. $\$ 380.1289$ (West Supp. 1984-85); N.C. Gen. Stat. $\S 115 \mathrm{C}-47(4)(1983)$.

110. See, e.g., Fla. Stat. AnN. $\$ 230.23(2)$ (West 1977); Mich. Comp. Laws Ann. $\$ 380.1300$ (West Supp. 1984-85).

111. See, e.g., Fla. Stat. ANN. § 230.23(8) (West 1977) (transportation of students); Ill. ANN. Stat. ch. 122, § 10-22.4 (Smith-Hurd 1962 \& Supp. 1984-85) (dismissal of teachers); Mrсн. Comp. LAWS ANN. § 380.1272 (West Supp. 1984-85) (supplying food to students and employees).

112. Pierce v. Society of Sisters, 268 U.S. 510 (1925).

113. See Board of Educ., v. Pico, 457 U.S. 853 (1982) (ban on books school board disliked may violate first amendment); Meyer v. Nebraska, 262 U.S. 390 (1923) (ban on teaching foreign language was unconstitutional).

114. See Medeiros v. Kiyosaki, 52 Hawaii 436, 478 P.2d 314 (1970) (parents may not prevent state from showing sex education films when parents have option to withdraw their children from showings). But see Engel v. Vitale, 370 U.S. 421 (1962) (state may not require recitation of state- 
Similarly, the federal government may impose its will upon state and local governments as to who will be allowed access to public education and on what terms, ${ }^{115}$ but it may not control the substance of what is taught in the schools.

Federal aid programs, which have inserted a more tangible federal presence in education than have judicial decisions, have also been concerned primarily with enlarging access to education. These programs have tied funds for serving target populations to regulations with which local and state educational agencies must comply. These aid programs, however, are quite different in structure and intent from the EAHCA which, by comparison, is both "unusually specific"116 and more far-reaching. First, the conditions attached to aid programs generally affect only the aid made available under the programs and do not restrict the use of other school monies. ${ }^{117}$ The EAHCA, in contrast, only covers about 25 percent of the extra cost of educating the handicapped child or about 9 to 14 percent of the total cost of the handicapped child's education. ${ }^{118}$ Conditions attached to other aid programs generally focus on the eligibility for new or enhanced services and programs, not the content and priorities of programs that already exist. 119 Finally, other aid

composed prayers in school, even if children may be excused); Abington School Dist. v. Schemp, 374 U.S. 203 (1963) (state may not require Bible readings or recitation of Lord's Prayer in schools).

115. See Brown v. Board of Educ., 347 U.S. 483 (1954) (racially segregated school are unconstitutional); Plyler v. Doe, 457 U.S. 202 (1982) (public schools may not exclude students who are illegal aliens). But see San Antonio Indep. School Dist. v. Rodriguez, 411 U.S. 1 (1973) (states not required to equalize funding to different school districts).

116. Cohen, Policy and Organization: The Impact of State and Federal Educational Policy on School Governance, 52 HaRv. Educ. Rev. 474, 489 (1982).

117. See, e.g., Education Consolidation and Improvement Act of 1981, 20 U.S.C. §§ 3801-3807 (Supp. 1984); Silverstein, Federal Approaches for Ensuring Equal Opportunity: Past, Present, and Future 15 (Nov. 1981) (unpublished paper); see also Bilingual Education Act, 20 U.S.C. $\S \S 3221$-3223, 3231-3233, 3241-3242, 3251-3252, 3261 (1982); Levin, supra note 70, at 171-72.

118. See Note, Board of Education v. Rowley, supra note 8, at 292 n.93; Miller \& Miller, supra note 74, at 17; Hartman, Policy Effects of Special Education Funding Formulas, 6 J. Educ. Fin. 135, 151 (1981); Colley, supra note 11 , at 137,144 .

Federal funds under the EAHCA are made available to states and distributed to local districts on the basis of the number of handicapped children served, up to a limit of 12 percent of the total school population, without regard to the nature of the services actually provided. 20 U.S.C. $\$ 1411(\mathrm{a})(5)(\mathrm{A})(\mathrm{i})(\mathrm{d})(1982)$. States must distribute 75 percent of the federal funds they receive directly to local districts, id. $\S 1411$ (c)(1)(B), and must pay a portion of the 25 percent they retain for direct services, id. $\S 1411$ (c)(2)(A). States must also match the funds distributed to local districts with nonfederal funds, id. $\$ 1411$ (c)(2)(B). This money and the portion of the 25 percent they distribute for direct services can be distributed in accordance with various reimbursement formulas which carry different sets of incentives. MoOre, Walker \& Holland, supra note 3, at 24-26, 77-78. See generally Barro, Federalism, Equity, and the Distribution of Federal Education Grants 2 (February, 1983) (unpublished paper); Hartman, supra.

Appropriation levels were expected to increase from 5 percent of the extra cost of educating a handicapped child in 1977 to 40 percent in 1982. 20 U.S.C. $\$ 1411$ (a)(1)(B) (1982). Actual federal appropriations have been considerably less, with only 29 percent of the possible amount (of $\$ 3.16$ billion) allocated in fiscal year 1982 . One estimate is that in fiscal year 1978, states received approximately $\$ 74$ per handicapped child, while in 1980 and 1981 , the figure was in the $\$ 200$ to $\$ 250$ range. Hartman, supra, at 153. A useful table illustrating the gap between federal funds authorized and funds appropriated under the EAHCA from 1978 to 1982 is found in Pittenger \& Kuriloff, Educating the Handicapped: Reforming a Radical Law, 66 PuB. INTEREST 72, 87 (1982).

119. Compare, e.g., School Lunch Program, 42 U.S.C. \$ $\$ 1751-1761$ lc (1982); School Milk Program Extension Act, P.L. 85-478, 72 Stat. 276 (1958) (expired 1961); Bilingual Education Act, 20 U.S.C. $\S \S 3221-3223,3231-3233,3241-3242,3251-3252,3261$ (1982); Career Education and De- 
programs do not create enforceable individual rights for particular services, but rather only eligibility to compete for additional limited monies distributed by decisionmakers who have considerable discretion. ${ }^{120}$

Federal nondiscrimination statutes also differ in many respects from the EAHCA. Section 601 of the Civil Rights Act of $1964^{121}$ prohibits discrimination in public education by the recipient of any federal funds on the basis of race, sex, or national origin. Section 504 of the Rehabilitation Act of 1973 prohibits discrimination against the handicapped by any recipient of federal funds. ${ }^{122}$ Like federal grant-in-aid statutes, however, these statutes affect access to, but not the content of, educational programming. Thus, while Title VI may prohibit a school district from using practices which deny national origin minority children effective participation in the educational program, ${ }^{123}$ it does not impose specific educational priorities, methods, or procedures upon school districts in implementing this nondiscrimination mandate. ${ }^{124}$ Section 504 of the Rehabilitation Act of 1973 is likewise a nondiscrimination statute, ${ }^{125}$ and even though it has been interpreted in the education setting according to guidelines very similar to those issued under the EAHCA ${ }^{126}$ and has been held to require school districts to provide an appropriate education to handicapped children, ${ }^{127}$ cases interpreting section 504 to require affirmative relief generally reach this conclusion through an analysis that piggybacks section 504 onto the more detailed and demanding provisions of the

velopment Program, 20 U.S.C. $\$ \S 2501-2569$ (1982), with 20 U.S.C. $\S \S 1412(5)(B)$, $1414(\mathrm{a})(1)(\mathrm{C})(1982) ; 34$ C.F.R. $\$ \$ 300.500-.556(1983)$ (least restrictive alternative preference). See Levin, supra note 74, at 171-72.

120. See P. Hill \& D. MADEY, supra note 58, at 2.

121. 42 U.S.C. $\S 2000$ d (1982).

122. 29 U.S.C. $\$ 794$ (1982).

123. See Lau v. Nichols, 414 U.S. 563 (1974) (local schools may not refuse to teach a large number of non-English speaking children in their native languages).

124. Courts have disagreed over the nature of the affirmative duties required by schools under Title VI on behalf of non-English speaking children. Compare Cintron v. Brentwood Union Free School Dist., 455 F. Supp. 57, 64 (E.D.N.Y. 1978) (must comply with "Lau guidelines" drafted by the Office of Civil Rights, requiring bilingual-bicultural program) with Guadalupe Org., Inc. v. Tempe Elementary School Dist., 587 F.2d 1022, 1029 (9th Cir. 1978) (remedial English satisfies Title VI). See Levin, supra note 70, at 174-75. Levin also points out that it is not clear that Title VI requires any affirmative action for non-English speaking children where the number of such students is small. Id. at 178 .

125. See Southeastern Community College v. Davis, 442 U.S. 397, 410-11 (1979).

Title IX of the Education Amendments of 1972, 20 U.S.C. $\$ \S 1681-1686$ (1982), similarly prohibits discrimination in all aspects of public education but does not require affirmative remedies on behalf of women, except as may be necessary to remove the effects of past discrimination. 34 C.F.R. $\S 106.3(\mathrm{a})$ (1984).

126. See, e.g., 34 C.F.R. \& 104.33(a) (1984) (requirement of free and appropriate education); id. $\S 104.35$ (placement and evaluation requirements); id. $\S 104.36$ (procedural due process safeguards). The section 504 regulations, in fact, make explicit reference to the standards of the EAHCA. See, e.g., 34 C.F.R. $\$ 104.33(b)(2)$ (1984) (compliance with IEP requirement of EAHCA meets burden of free and appropriate education under section 504).

127. See, e.g., Georgia Ass'n of Retarded Citizens v. McDaniel, 716 F.2d 1565 (11th Cir. 1983), vacated on other grounds, 104 S. Ct. 3581 (1984); New Mexico Ass'n for Retarded Citizens v. New Mexico, 378 F.2d 847 (10th Cir. 1982); David H. v. Spring Branch Indep. School Dist., 569 F. Supp. 1324 (S.D. Tex. 1983); Association of Retarded Citizens v. Frazier, 517 F. Supp. 105 (D. Colo. 1981). North v. District of Columbia Bd. of Educ., 471 F. Supp. 136 (D.D.C. 1979). 


\section{EAHCA. ${ }^{128}$}

Federalism raises a difficult problem under the EAHCA. On the one hand, it would seem that the handicapped need the coercive power of federal government applying uniform and enlightened standards of conduct in order to reverse local prejudice and ignorance and to protect their basic interests. ${ }^{129}$ On the other hand, state and local control of education is likely to enhance the effectiveness of education, from which all students benefit. The freedom to participate in public life, to influence political decisions, to obtain relevant information, and to hold those who act on one's behalf directly accountable, are all considered particularly valuable with respect to a governmental service such as education which, regardless of the ultimate basis of power, must be delivered on a local and decentralized basis. Decentralization is thought to keep local communities concerned, active, and vigilant in public school systems, ${ }^{130}$ which then encourages accountability by those who can make the biggest difference in the quality of education-teachers and school

128. See, e.g., Rettig v. Kent City School Dist., 539 F. Supp. 768, 776 (N.D. Ohio 1981) (collapsing discussion of EAHCA and section 504), aff'd in part, rev'd in part on other grounds, $720 \mathrm{~F} .2 \mathrm{~d} 463$ (6th Cir. 1983); Campbell v. Talladega County Bd. of Educ., 518 F. Supp. 47, 51 (N.D. Ala. 1981) (focusing on provisions of the EAHCA because they provided "a far more detailed statutory framework" than section 504); Gladys J. v. Pearland Indep. School Dist., 520 F. Supp. 869, 874-75 (S.D. Tex. 1981) (mentioning the section 504 claim and then ignoring it); see also North v. District of Columbia Bd. of Educ., 471 F. Supp. 136, 139 (D.D.C. 1979) (deciding for the child under both section 504 and the EAHCA without analyzing separately the applicability of each statute).

Despite the more specific provisions of the EAHCA, section 504 claims are often brought in addition to the EAHCA claims because of the different procedural requirements and remedies available under section 504. See, e.g., Georgia Ass'n of Retarded Citizens v. McDaniel, 716 F.2d 1565 (11th Cir. 1983) (injunctive relief sought under section 504), vacated on other grounds, 104 S. Ct. 3581 (1984); Phipps v. New Hanover County Bd. of Educ., 551 F. Supp. 732 (E.D.N.C. 1982); Patsel v. District of Columbia Bd. of Educ., 530 F. Supp. 660 (D.D.C. 1982) (attorney fees available under section 504); Association for Retarded Citizens v. Frazier, 517 F. Supp. 105 (D. Colo. 1981) (plaintiffs not required to exhaust administrative remedies under section 504). The Supreme Court has put into question these strategies, holding last term that section 504 was inapplicable in a case in which relief had been granted under the EAHCA. Smith v. Robinson, 104 S. Ct. 3457 (1984) (plaintiff sought attorney fees under section 504).

The major case which responded to section 504 without also deciding the EAHCA claim held that a failure to diagnose, identify, and assimilate handicapped children into public school classes would violate the Rehabilitation Act. See New Mexico Ass'n for Retarded Citizens v. New Mexico, 678 F.2d 847 (10th Cir. 1982). At the time of this decision, New Mexico did not accept federal funds under the EAHCA, and thus was not subject to its provisions. Id. at 853 .

129. See supra note 75 ; infra note 138 and accompanying text.

130. See Milliken v. Bradley, 418 U.S. at 717, $741-42$ (1974) (“[L]ocal autonomy has long been thought essential both to the maintenance of community concern and support for public schools and to the quality of the educational process."); Wright v. Council of Emporia, 407 U.S. 451,469 (1972) ("[d]irect control over decisions vitally affecting education of one's children is a need that is strongly felt in our society. . . ."); Thompson v. Engelking, 96 Idaho 793, 803, 537 P.2d 635, 645 (1975). The Thompson court stated:

The American people made a wise choice early in their history by not only creating forty-eight state systems of education, but also by retaining within the community, close to parental observation, the actual direction and control of the educational program. This tradition of community administration is a firmly accepted and deeply rooted policy.

Id. at 803, 537 P.2d at 645 (quoting Andrus v. Hill, 73 Idaho 196, 200, 249 P.2d 205, 207 (1952)).

This view is often attributed to the Reagan Administration as the impetus behind efforts at greater decentralization in education. See Clark \& Amiot, The Impact of the Reagan Administration on Federal Education Policy, 63 Phi Delta Kappan 258, 258 (1981). See also Levin, supra note 99, at 444-45. (decentralized decisionmaking promotes accountability to those most affected by the decisions); 
administrators. ${ }^{131}$ The enhanced authority of service providers on the local level increases their effectiveness in another way as well, for when such individuals are given more responsibility they tend to act more diligently and effectively than when they are not. ${ }^{132}$

Decentralization also capitalizes on the positive potential of experimentation and diversity. ${ }^{133}$ Where various solutions are possible, decentralization encourages choices that enrich liberty and freedom of choice and permits the observation and testing of hypotheses which will yield better answers for adoption by others with common problems. ${ }^{134}$ This experimentation is thought to be especially beneficial in public education. ${ }^{135}$

The federalism tension in public education, like the tension between need and merit and the tension between individualized and collective decisionmaking, did not originate with the EAHCA but has been highlighted and aggravated by it. In the next section, I attempt to define a theoretical framework that will assist in mediating (though not eliminating) these tensions.

\section{Defining The Ideal}

The tensions defined in part III arise from the attempt to assist certain individuals who, because of their special characteristics, are at a disadvantage in relation to the majority in obtaining the benefit of a public service. Such stress has been demonstrated in other areas of civil rights and is perhaps inevitable in efforts to eliminate hardship that befalls a special group from the operation of otherwise neutral rules. When these tensions have important

Steiner, A Progressive Creed: The Experimental Federalism of Justice Brandeis, 2 Yale Law \& Pol'y Rev. 1, 38 (decentralization promotes civic virtue).

131. See David \& Greene, supra note 74, at 122, 124.

132. See R. Elmore, Complexity and Control: What Legislators and Administrators Can Do About Implementation (Institute of Governmental Research, Public Policy Paper No. 11, 1979), excerpted in $M$. Yudof, D. Kirp, T. van Geel \& B. Levin, Educational Policy and the Law 658-75 (2d ed. 1983). See also Wieman v. Updegraff, 344 U.S. 183, 196 (1952) (Frankfurter, J., concurring) ("[teachers] cannot carry out their noble task if the conditions for the practice of a responsible and critical mind are denied to them"); Odden, Financing Educational Excellence, 66 Phi Delta KapPan 311,312 (1984) ("The research on effective schools has made it clear that the individual school is the proper unit for educational renewal. Centralized standards and requirements may be necessary, but so is decentralized implementation. . . Each effective school is bound together by a belief structure, a value system, and a consensual-not a hierarchical-governance system.").

133. "It is one of the happy incidents of the federal system that a single courageous state may, if its citizens choose, serve as a laboratory; and try novel social and economic experiments without risk to the rest of the country." New State Ice Co. v. Liebmann, 285 U.S. 262, 311 (1932) (Brandeis, J., dissenting); see also Addington v. Texas, 441 U.S. 418, 431 (1979) ("The essence of federalism is that states must be free to develop a variety of solutions to problems and not be forced into a common, uniform mold.').

134. See B. ACKerman, supra note 13, at 306 ("Federalist structures . . permit the polity to make creative use of the fact that many second-best problems admit of a wide variety of legitimate solutions."). Ackerman notes as limits of federalism and other "process strategies," however, that " [w] hile they may well reduce the risk of governmental tyranny, they often increase the risk of private exploitation." Id.

135. See San Antonio Indep. School Dist. v. Rodriguez, 411 U.S. 1, 50 (1973) (local control over the educational process encourages "experimentation, innovation, and a healthy competition for educational excellence'). 
cost implications, they pose risks of unfairness to society at large. The creation of unique, individualized, and costly rights for the handicapped in public education burdens a system which has legitimate, worthy goals and upon which a large proportion of children depend for an essential service. There must be limits to the weight of this burden. As Bruce Ackerman states in a more general context, "[h]owever valid X's claims against his fellow citizens, it hardly follows that his treatment can serve as the exclusive touchstone of economic and social policy in a just society." 136

This dilemma creates the need for a principle which will mediate the interests of particular individuals and the interests of society at large and will define a fair relationship between the entitlements of the protected class and the interests of the remainder of society. This section first outlines the characteristics of handicap relevant to the formulation of this relationship. It then reviews and evaluates various conceptions of equality that might be used as a basis for this relationship.

\section{A. The Nature of Handicap}

Handicap is not defined by a single characteristic, such as skin color, national origin, sex, or religious preference. Handicaps vary in type and degree, with differing effects upon an individual's ability and hence upon the likelihood of achieving certain educational goals. ${ }^{137}$ Some conditions perceived to be handicaps are not in fact handicapping conditions; they are differences without significance except that which may be artificially given to them by others. Children with disfigurements or features which make them unusual or unsightly might be unwelcome in public schools, but the lack of hospitality is due not to a rational relationship between the handicapping condition and the activities that take place in the school, but rather to irrational or unreasonable discriminations attached to those handicaps by others. ${ }^{138}$ The effects of these handicaps can be neutralized without special compensation or treatment, other than that which might make the child more welcome or understood in the educational institution.

Most handicaps, on the other hand, are true handicaps affecting the value or utility of educational services that might be offered to children who have them. The handicaps are thus relevant to the education which is made avail-

136. B. Ackerman, supra note 13, at 271 (emphasis added).

137. See Moore, Walker \& Holland supra note 3, at 7-9; Sorgen, The Classification Process and Its Consequences, in The Mentally Retarded Citizen and the Law 215 (1976); Large, supra note 74 at $214,238-40$.

138. See, e.g., State ex rel. Beattie v. Board of Educ., 169 Wis. 231, 232, 172 N.W. 153, 154 (1919) (paralytic boy with "slow and hesitating speech" and a "peculiarly high, rasping, and disturbing tone of voice, accompanied with uncontrollable facial contortions" and "an uncontrollable flow of saliva, which drools from his mouth onto his clothing and books, causing him to present an unclean appearance" excluded from school because "his physical condition and ailment produces a depressing and nauseating effect upon the teachers and school children; . . . he takes up an undue portion of the teacher's time and attention, distracts from the attention of other pupils, and interferes generally with the discipline and progress of the school"). For a follow-up on the child involved in this case, see Blakely, supra note 77 , at 603-05. 
able to handicapped children or to which they may be entitled. True handicaps cover a wide universe, and problems of definition, identification, and professional disagreement about teaching methods and theories make predictions and generalizations about many of them difficult and/or controversial. ${ }^{139}$ Some handicaps are mild, at least as to their impact on the objectives of public education. These can be eliminated with only modest adjustments in a child's educational program. A mobility impairment, for example, may be corrected as to nearly all activities offered to students through the availability of a wheelchair and ramps or other devices that allow free access to the educational facilities. A mild speech impediment may, after a brief time, be eliminated by speech therapy.

Other handicaps pose greater difficulties with respect to the objects and design of public education. The educational effects of these handicaps can be virtually eliminated in some cases, but may require more than modest adjustments to the standard educational program in order to do so. A deaf child, for example, may need a sign-language interpreter in order to understand all of what is said in school during the day. Still other handicaps, such as severe retardation, render a child incapable at any cost, through existing technology, of achieving the same goals that are set for nonhandicapped children.

In addition to the variety of types and degrees of handicap, children with handicaps may differ with respect to individual tastes, interests and goals, rendering the effects of their handicap more or less disabling to them. These differences affect the type and degree of remediation that might be desired by a handicapped person. The blind child who wishes to become a nurse, for example, will be considerably more burdened by the legitimate requirements of the profession ${ }^{140}$ than the blind child who wishes to be a writer or a musician. Likewise, the individual's other talents, weaknesses, or life circumstances may temper or magnify the effects of a handicap. For instance, low intelligence may aggravate the handicapping condition of deafness while a high intelligence may ameliorate it. An unstable family life may distract the handicapped child from an already difficult learning activity; a child with handicaps who enjoys a warm, stable home life, may respond extremely well to remedial assistance. ${ }^{141}$

The fact that handicap encompasses some of the very qualities which would otherwise render discriminations valid-ability, wit, speed, sense of humor, size, ambition, and so on-creates a dilemma which partially explains the tenacity and insidious nature of disparate treatment based upon handicap.

139. See Moore, Walker \& Holland, supra note 3, at 7-9, 11 -12; Stark, supra note 2, at 488-91, 497, 504-05. See also supra note 78.

140. See, e.g., Southeastern Community College v. Davis, 442 U.S. 397, 407 (1979) (hearingimpaired applicant for nursing program).

141. See, e.g., Springdale School Dist. v. Grace, 494 F. Supp. 266, 272 (W.D. Ark. 1980) ("The home life of the child, his parents' interests and the child's cultural and sociological environment often determine the child's academic success and attainment or lack of such."), aff'd, 656 F.2d 300 (8th Cir. 1981), vacated, 458 U.S. 1118 (1982), affd on rehearing, 693 F.2d 41 (8th Cir. 1982), cert. denied, 461 U.S. 927 (1983); Placing Children in Special Education, supra note 87, at 16, 167-69 (home environment may affect outcome on tests and hence educational placements). 
These qualities of handicap appear to provide a factual explanation for different outcomes in learning, thus confusing us as to what constitutes fair treatment.

The issue of fair treatment is complicated when cost is raised as a factor to limit educational services for a handicapped child. Costs are a limiting factor, and society resists diverting resources from other purposes, especially where others assert competing claims to the resources demanded by the handicapped. The issue of cost in special education must be answered by reference to a concept of fairness relating the entitlements of the handicapped child to the claims of others. In the next section I explore and evaluate some alternatives.

\section{B. Alternative Forms of Equality}

Because genuine, relevant differences exist between the handicapped and the nonhandicapped, certain formulations of equality that are appropriate between members of other groups seem unsatisfactory when applied to the handicapped. Formal equality, for example, providing identical legal right of access to a service, would give handicapped children permission to enter public schools, but would go no further. Because formal equality does not treat differences between individuals affecting their ability to obtain value from such service as relevant, that service will not enable the handicapped to benefit from it. ${ }^{142}$ Formal equality requires no special accommodations or remediation to eliminate differences affecting a child's ability to use or benefit from formal access, and thus would at most only legitimate continued lack of effective access by handicapped children who cannot benefit from regular educational programs. This approach is not argued seriously in cases arising under the EAHCA, ${ }^{143}$ and contentions that a particular type of service is not required because it has no parallel in regular education programs are generally rejected. ${ }^{144}$

Value equalization might seem a more attractive form of equality between the handicapped and the nonhandicapped in public education. ${ }^{145}$ Value equalization, which equalizes the objective value of resources made available to children, makes allowances for individual abilities, tastes, and needs, requiring the distribution of resources equally to individuals who can then use the resources with some degree of (perhaps total) discretion. In education, value equalization would allow individuals to have different educational pro-

142. This shortcoming follows in large part from a superficial view of what characteristics are relevant in determining equality of treatment. See J. Feinberg, Social Philosophy 100 (1973).

143. The EAHCA, in fact, specifies that funds disbursed under it are to be used only for "excess costs," that is, costs over and above the school's average annual expenditures. 20 U.S.C. $\S \S 1401(20), 1414(\mathrm{a})(1)(1982)$.

144. See, e.g., Kruelle v. New Castle County School Dist., 642 F.2d 687, 693 (3d Cir. 1981) (rejecting argument that 6-hour day program would be appropriate for a profoundly retarded child since nonhandicapped children had only 6-hour day program); Battle v. Pennsylvania, 629 F.2d 269 (3d Cir. 1980) (180-day rule), cert. denied, 452 U.S. 968 (1981).

145. Arthur Wise calls this form of equality the "equal-dollars-per-child" definition. A. WiSE, supra note 88 , at $155-56$. 
grams and services so long as the programs and services required equivalent resource expenditures. Value equalization would be helpful to children whose needs are different from other children but who do not require a greater total amount of resources. Most handicapped children, however, do not fall into this category. ${ }^{146}$ The vast majority of the needs of the handicapped are not only different from, but also greater, in terms of resources, than those of the nonhandicapped; for them, value equality will address only a portion of their needs in comparison to other children.147 Like formal equality, value equalization has not, since the enactment of the EAHCA, been seriously advanced as the appropriate relationship between handicapped and nonhandicapped children in public education.

Equalization of results or outcomes has received more serious attention. Outcome equality "permits wide disparities in the allocation of education resources so long as the different needs of children are being met in a way that results in equality in the effects of the schooling process." 148 Because results or outcome in education depend heavily upon highly individualized factors such as personal effort, this form of equality is usually expressed in terms of equalized opportunity. ${ }^{149}$ In its more extreme form, this approach would require elimination of the effects of the handicap that bear on the child's ability to benefit from the education offered to him. ${ }^{150}$ Thus, if a nonhandicapped child receives a certain amount of resources in order to reach certain educational goals, the handicapped child would have a right to whatever resources are necessary to reach the same goal.

Differences in goals among children, both handicapped and nonhandicapped, make outcome equality problematic. ${ }^{151}$ On the basis of these goals, the resources to which children lay claim may vary considerably. ${ }^{152} \mathrm{~A}$ child who wishes to become an unskilled laborer may ask much less in the way of educational resources than one who decides to pursue a medical career. Factors other than handicap which may impede or facilitate the accomplishment of certain goals such as a bad diet or unstable homelife, may also affect the ability of children to benefit from education resources. If, however, the effects of handicap could be isolated (or the definition of handicap sufficiently broadened to take into account all disadvantaging factors in one's life), ${ }^{153}$ particular goals could be set-such as reading at a "tenth grade" level or self-suffi-

146. See Kakalik supra note 2, at 339-43 (10-12 percent).

147. See supra note 3.

148. Yudof, supra note 85 , at 419 .

149. Equality of opportunity and equality of results are often viewed as contrasting forms of equality. See Bell, supra note 85 ; Coleman, supra note 60 . Both equality of opportunity and equality of results, however, focus on the end product rather than on the resources that may be required to reach that end. Ronald Dworkin refers to that end product as "welfare." Dworkin, What Is Equality? Part 1: Equality of Welfare, 10 Phil. \& Pub. Affairs 185 (1981).

150. This approach is essentially the approach taken by the trial court in Rowley v. Board of Educ., 483 F. Supp. 528 (S.D.N.Y.), affd, 632 F.2d 945 (2d Cir. 1980), rev'd, 458 U.S. 176 (1982).

151. See supra notes 140-41 and accompanying text.

152. See Dworkin, What Is Equality? Part 2: Equality of Resources, 10 PhiL. \& Pub. Afrairs 283, 285-86 (1981).

153. See supra note 87 and accompanying text. 
ciency ${ }^{154}$-and resources distributed in a manner that would neutralize the effects of any handicap and equalize the handicapped child's chances of achieving those goals.

The more basic difficulty with outcome equality is that it puts unrealistic demands on both resources and educational goals. There is first the question of feasibility. For many children, handicaps render them incapable under the present state of the art to achieve average, or even minimal, educational goals regardless of the manner of resource allocation. Even if goals are limited to those an individual child is capable of achieving, difficulties remain. For many handicapped children, the cost of educational achievement will be extraordinarily high. The only way to address a shortfall of resources under outcome equality is to adjust the goals that all children are given the opportunity to achieve. This approach, however, ignores the merit-based orientation of public education, and trades off the education of "normal" and higher functioning children to the education of children of the lower ability levels. ${ }^{155}$

This outcome equality approach to distributing educational resources will result in a quality of education to children generally that does not serve society, or even the handicapped, well. ${ }^{156}$ This method would be grossly inefficient in other respects as well. The gains to the handicapped child from such a distribution may be slight and the disutility of shifting resources from the nonhandicapped to the handicapped enormous. Equality may be furthered, but entirely at the expense of efficiency and common sense. For even the more thoroughgoing redistributionists, a point is reached at which the resources needed to accomplish the next increment of equality of results are considered too great in light of the sacrifices that would be required. ${ }^{157}$

To reduce the inefficiency and, in many cases, the infeasibility of achieving

154. Some courts have identified the goal of self-sufficiency as the goal of the EAHCA and the end toward which educational services should be aimed. See Campbell v. Talladega County Bd. of Educ., 518 F. Supp. 47, 53-54 (N.D. Ala. 1981); Armstrong v. Kline, 476 F. Supp. 583, $603-04$ (E.D. Pa. 1979), aff'd on other grounds sub nom. Battle v. Pennsylvania, 629 F.2d 269 (3d Cir. 1980), cert. denied, 452 U.S. 968 (1981). See also Comment, Self-Sufficiency Under the Education for All Handicapped Children Act: A Suggested Judicial Approach, 1981 DukE L.J. 516; Note, Defining an "Appropriate Education," supra note 8, at 106-09; Note, The Education for All Handicapped Children Act: What Is a "Free Appropriate Public Education"?, 29 WAYNE L. REv. 1285, 1291 (1983). This approach was also suggested by Judge Mansfield, dissenting from the court of appeals' decision to affirm in Rowley v. Board of Educ., 632 F.2d 945, 952-53 (2d Cir. 1980), but was rejected by the U.S. Supreme Court. 458 U.S. 176,201 n.23 (1981).

155. Cf. B. Ackerman, supra note 13, at 18 (describing the "nightmare world where all human diversity has been destroyed in the name of an equality that levels everyone to the lowest common denominator").

156. Cf. J. Rawls, A Theory of Justice 78 (1971) (describing the "difference principle," which justifies inequalities in resource allocation only if necessary to improve the position of the worse-off in society).

157. See, e.g., B. Ackerman, supra note 13, at 270 ("[W]hatever the strain placed on statesmanly judgment the standard of negative compensation does not impose the insatiable demand implied by a maximizing principle."); Frankel, supra note 82, at 201 ("Some general system of social cost accounting, which assigns different values to the satisfaction of different wants, . . has to be employed."); J. Fishkin, supra note 83, at 46. See also Dworkin, supra note 152, at 297-300 (developing insurance model to set upward limit on extraordinary expenses for individuals with extraordinary needs); Baker, Outcome Equality or Equality of Respect: The Substantive Content of Equal Protection, 131 U. PA. L. REv. 933, 941 (1983); infra note 186. 
outcome equality, one might seek instead to allocate resources so that all children have the opportunity to reach certain minimal goals, distributing any remaining resources to children with higher potential so that they may attain further goals. This reallocation principle would permit equality in the opportunity to achieve at certain minimum levels (at least insofar as a child is capable of reaching such a level), ${ }^{158}$ higher levels being available according to criteria that may discriminate on the basis of handicap. This approach requires the definition of the minimum educational levels to be afforded to students regardless of handicap. The factors which make this task especially problematic are outlined below in the discussion of Board of Education $v$. Rowley. ${ }^{159}$

Instead of equalizing the opportunity to attain certain standardized results, one might attempt to equalize the opportunity to attain reasonable educational goals set in accordance with each child's own particular needs. This variation of equality aims at equalizing the likelihood of reaching goals that are equivalently suitable for each person, ${ }^{160}$ and responds to limitations in resources by scaling down the programs proportionately for all children so that they are subjected equally to the effects of resource shortfall. This approach pursues parity, acknowledging that needs vary but that the strength of an individual's claim for limited resources should not. I develop this approach further in the following section.

\section{Program Parity}

Program parity requires that educational needs be identified for every child and programs hypothesized to satisfy those needs. Resource availability would then determine what portion of a child's needs could be met, and schools would adjust programs so that each child would be afforded the same portion (or relative deprivation) as others. ${ }^{161}$ The purpose of this standard is to ensure that in allocating scarce resources, some students are not favored

158. See Stark, supra note 2, at 499; Haggerty \& Sacks, Education of the Handicapped: Towards a Definition of an Appropriate Education, 50 TEMP. L.Q. 961, 974-75 (1977). This is essentially the approach taken by the Supreme Court in interpreting the EAHCA in Board of Educ. v. Rowley, 458 U.S. 176 (1981).

159. 458 U.S. 176 (1982); see infra text accompanying notes 174-76.

160. This principle might be confined to handicapped children who are incapable, regardless of program, of reaching the same goals that would otherwise be set for nonhandicapped children. It might also be appropriate, however, where there is an intolerably large disparity between the incremental advances in achievement (made possible by additional resources) attainable by handicapped and nonhandicapped children.

161. Judith Wegner has described this approach as an "equivalent opportunity" test, and criticized it for its lack of judicially manageable criteria. Wegner, Variations on a Theme-The Concept of Equal Educational Opportunity and Programming Decisions Under the Education for All Handicapped Children Act of 1975, Law \& Contemp. Probs., Winter 1985, at 169, 184-85, 192-93. The district court in Rowley v. Board of Educ., 483 F. Supp. 528, 534 (S.D.N.Y. 1980), set forth a similar standard, but with quite different implications. This standard required that the shortfall between a handicapped child's potential and his or her performance be measured and then compared to the shortfall experienced by nonhandicapped children. Id. Because potential was determined in Rowley without regard to the child's physical handicap, the standard, as applied in that case required that the effects of the child's handicap be eliminated as far as possible. A number of commentators have made a similar move, describing first a comparability-of-opportunity standard and then applying a standard in which the effects of handicap are to be eliminated. See Note, Enforcing the Right, supra note 8, at 1125-27; 
over others. More precisely, the standard ensures that decisionmakers do not disfavor members of certain targeted groups and make them absorb more than their fair share of the effects of resource scarcity.

The concept of program parity begins with the identification of "first-rate" educational programs. A first-rate educational program is not one for which improvements cannot be imagined, but rather one that is reasonably comprehensive and which adopts the highest standards of practice among professionals in the field. There is reason to believe that such programs can be identified, at least in general categories. ${ }^{162}$ Theoretically, one could begin this process by defining an optimal program, and work down from there in parallel fashion for all educational programs.

There are many practical problems even at this first stage. Just as educational minimums are extremely problematic, ${ }^{163}$ so educational maximums are elusive as well. One can nearly always imagine additional incremental services of higher quality programs that could be offered to a student to improve his opportunity for learning-additional tutoring, for example, or teacher pay raises. Moreover, developing hypothetical programs that are not ultimately affordable will be considered a wasteful effort, effort that would be better spent in providing direct educational services. Still further, comparisons of quality will be difficult, and the threshold questions to sort out nearly endless: With what children and with what programs should determination of needs and quality of program be made for purposes of comparison with the programs offered to handicapped children? By what measures will needs be determined? By what standards will the quality of programs be judged? How can shortfall be measured? On what basis could one conclude that the programs for numerous different groups of children be rated as "comparable" to a first-rate program for a handicapped child? Is it possible to compare, for example, the quality of a resource center for the learning disabled or the selfcontained classroom for a moderately retarded child with the regular fifth grade program of a nonhandicapped child or the special library period for the gifted?

These difficult questions have influenced courts to avoid application of comparative standards. ${ }^{164}$ The high degree of skepticism shown over such comparisons, however, is unwarranted. Comparative judgments about the

\footnotetext{
Note, Attack on the EHA: The Education for All Handicapped Children Act After Board of Education v. Rowley, 7 U. Puget Sound L. Rev. 183, 189 n.46 (1983) [hereinafter cited as Note, Attack on the EHA].

162. See Jordan \& Stultz, Projecting the Educational Needs and Costs of Elementary and Secondary Education, in Educational Need in the Public Economy 163, 177 (1976) (establishing weights for making cost estimates of special education based upon practices by reputedly good or high quality programs). Haggerty \& Sacks, supra note 158 , at 989 n.170.

163. See infra section IV D.

164. See, e.g., Board of Educ. v. Rowley, 458 U.S. 176, 198 (1981) (requirement of equal educational opportunities an "unworkable standard requiring impossible measurements and comparisons"); cf. San Antonio Indep. School Dist. v. Rodriguez, 411 U.S. 1, 25 (1972) (no system can assure equal quality of education, except in the most relative sense); McInnis v. Shapiro, 293 F. Supp. 327, 335-36 (N.D. Ill. 1968) (three-judge panel) (no manageable standards by which court can require expenditures by schools in relation to a child's need, or in equal amounts), affd sub nom. McInnis v. Ogilvie, 394 U.S. 322 (1969).
} 
quality of education are commonly made ${ }^{165}$-most persons would acknowledge the superiority of the education available in Scarsdale over Harlem-and many more refined comparisons are routinely made by educators. These judgments are at least as precise as those required under Board of Education $v$. Rowley to determine what educational services are required to permit a child to receive "some educational benefit."'166

Even where precise comparisons are difficult, program parity is a useful general guide to decisionmaking. It is the principle - the legal, political, and moral goal - that most accurately describes the nature of the task that policymakers should adopt in ensuring and implementing education for the handicapped. It is a principle that helps to apply more specific, though still elusive, standards such as an "appropriate education," and which suggests a vision of justice for the handicapped that can guide not only judges, but also legislators, regulators, service providers, and others upon whom the fate of handicapped children in the schools ultimately rests.

Under the program parity approach, the handicapped child will not be entitled to any particular level of services, so long as what the child is offered is comparable to the services offered to others in the school district. This approach is vulnerable to the criticism that the handicapped child in a poorer school district will be entitled to less than his counterpart in a wealthier district. This criticism highlights a deficiency in public education generally, however, rather than a weakness in the concept of program parity. Program parity does not require that the level of education generally available to children in all districts, including poor districts, be sacrificed so that handicapped children can enjoy services that are measurably superior to those offered to nonhandicapped children. By the same token, handicapped children in wealthy districts will not be limited by a level of average or minimal educational entitlements; their entitlements will be equal to the level of educational services available to nonhandicapped children. Program parity reflects, but does not aggravate, the wealth disparities among school districts in this country today.

The concept of program parity directly addresses the issue of cost in special education. It affirms that cost is a legitimate factor to take into account in determining what educational program should be offered to a handicapped child, as it is already in determining the level of educational programs available to nonhandicapped children. The program parity standard requires that consideration of cost be overt, open to scrutiny by reviewing courts, parents, and the public. It requires explicit analysis of the resource allocation issue and puts that analysis into view for possible response by parents, school offi-

165. See, e.g., Educational Evaluation Methodology: The State of the Art (R. Berk ed. 1981); Doud, NSSE Elementary School Evaluative Criteria: A Guide to School Improvement Through Evaluation, 56 North CENT. A.Q. 402 (1983). See also Kaden, Courts and Legislatures in a Federal System: The Case of School Finance, 11 Hofstra L. REv. 1205, 1212 (1983) (discussing measurements of school quality by educational outputs, educational inputs, and evaluations of school programs); cf. A. WISE, Legislated Learning 12-27 (1979) (educational evaluations focus on student achievement levels rather than quality of opportunities offered to students).

166. See 458 U.S. 176, 200-04 (1982). For a discussion of this standard, see infra section IV D. 
cials, and elected representatives. ${ }^{167}$

Program parity sets substantive limits on the extent to which cost may bear on program choice, refining the assertion often made that scarcity of funding should not be permitted to bear more heavily on handicapped than on nonhandicapped children. ${ }^{168}$ Where types of services exist that can be comparable between handicapped and nonhandicapped children, the concept of program parity suggests that the kinds of services that are offered to nonhandicapped children should ordinarily be offered to handicapped children as well. Cases holding that summer programs should be offered to handicapped children whenever they are offered to the nonhandicapped exemplify this analysis. ${ }^{169}$ Such parallelism, however, will in most cases be absent, and even where present it may suggest services that either fall short or go beyond the duty required under the program parity standard.

Program parity would encourage further scrutiny of comparisons between educational programs offered handicapped children and nonhandicapped children, to assess whether significant disparities in quality exist. Factors such as overcrowding, high student/teacher ratios, low teacher salaries, outdated

167. In fact, in establishing a substantive standard under which the issue of cost is apparently, but unrealistically, irrelevant, see supra notes 35-37 and accompanying text, the Court in Board of Educ. v. Rowley, 458 U.S. 176 (1982), drives the issue of cost underground, rendering it a more dangerous, less controllable factor in educational decisions that are made for handicapped children than the standard of program parity would allow. See infra note 186.

168. See, e.g., Crawford v. Pittman, 708 F.2d 1028, 1035 (5th Cir. 1983); Yaris v. Special School Dist., 558 F. Supp. 545, 559 (E.D. Mo. 1983), affd, 728 F.2d 1055 (8th Cir. 1984). This analysis is supported in legislative history of the EAHCA that cites language from Mills v. Board. of Educ., 348 F. Supp. 866,876 (D.D.C. 1972):

If sufficient funds are not available to finance all of the services and programs that are needed and desirable in the system then the available funds must be expended equitably in such a manner that no child is entirely excluded from a publicly supported education consistent with his needs and ability to benefit therefrom. The inadequacies of the . . . Public School System whether occasioned by insufficient funding or administrative inefficiency, certainly cannot be permitted to bear more heavily on the 'exceptional' or handicapped child than on the normal child.

S. ReP. No. 168, 94th Cong., 1st Sess. 23, reprinted in 1975 U.S. Code Conc. \& Ad. News 1425, 1447. This authority is somewhat ambiguous, for its meaning depends upon the weight given to the Mills language that no child should be entirely excluded from public education. The Supreme Court in Board of Educ. v. Rowley, 458 U.S. 176 (1982), clearly means to restrict the language in Mills to the exclusion of handicapped children from a meaningful education, not to define a right dependent upon "impossible measurements and comparisons." Id. at 198. "Mills . . . speaks in terms of "adequate' educational services, 348 F. Supp. at 878 , and sets a realistic standard of providing some educational services to each child when every need cannot be met." 458 U.S. at 193 n.15.

169. See, e.g., Yaris v. Special School Dist., 558 F. Supp. 545 (E.D. Mo. 1983), affd, 728 F.2d 1055 (8th Cir. 1984). If a school offers summer programs to nonhandicapped children, it would seem unfair to require handicapped children to make a showing that a summer program was necessary to prevent them from regressing in the gains experienced during the regular 180-day school year, as was at issue in Yaris. This requirement is typical in cases challenging the 180-day school year where summer programs are generally not available to any children. See Georgia Ass'n of Retarded Citizens v. McDaniel, 716 F.2d 1565, 1573-76 (11 th Cir. 1983), vacated, 104 S. Ct. 3581 (1984); Battle v. Pennsylvania, 629 F.2d 269 (3d Cir. 1980), cert. denied, 452 U.S. 968 (1981); Bales v. Clarke, 523 F. Supp. 1366 (E.D. Va. 1981); see also Irving Indep. School Dist. v. Tatro, 104 S. Ct. 3371 (1984) (catheterization for handicapped child comparable to school nurse services available to nonhandicapped); Helms v. Indep. School Dist. No. 3, 750 F.2d 820 (10th Cir. 1984) (handicapped children entitled to more than twelve years of public education where handicapped children permitted to repeat grades until they graduate). 
facilities, and limited materials in the school system might justify a lower level of services to handicapped children than if the school system enjoyed modern and ample facilities, the most advanced laboratory resources, the best-trained and most highly paid teachers, and the latest, innovative educational programs. ${ }^{170}$ Comparisons with spending patterns in other school districts or states, ${ }^{171}$ perhaps assisted by data and guidelines generated by a centralized administrative agency, would be helpful in evaluating spending patterns in a particular school district. ${ }^{172}$

Program parity identifies what is fair and just in terms of the district's ability to bear the cost of expensive programs. This ability to bear the cost is a factor used in resolving questions of cost under section 504 of the Rehabilitation Act of $1973^{173}$ and other nondiscrimination statutes. Under the program parity standard, however, the ability to bear the cost explicitly goes beyond what resources the district may have reserved for the handicapped, using the broader reference point of the level of quality the district is willing to fund for programs for nonhandicapped children.

The concept of program parity mediates the tensions between the EAHCA and the institutional context of public education described in part III of this article. It integrates individualized assessments into the institutional setting of collective decisionmaking by more precisely and accurately defining the problem in both individual and collective terms: how to marshal some fair share of public resources for the individual handicapped child for a service generally available to others. It resolves this problem by coordinating individualized and collective decisionmaking. Although need must be identified individually, the required level of educational services for the handicapped

170. See Note, Enforcing the Right, supra note 8, at 1126-27; Note, The Rowley Decision, supra note 11 , at 705 .

171. See, e.g., Crawford v. Pittman, 708 F.2d 1028, 1035 n.31 (5th Cir. 1983) ("Mississippi is not now parsimonious in its aid to the handicapped. In the 1979-80 school year, the state expended almost five dollars for the handicapped for every one dollar in federal funding it received for that purpose. For the $1978-79$ school year, the ratio was $\$ 7.30$ to $\$ 1.00 \ldots$. "); Garrity v. Gallen, 522 F. Supp. 171, 224 (D.N.H. 1981) (Whereas the national average of state money going to special education is 3.63 percent of every dollar spent on education, New Hampshire spends only .9 percent of every dollar on special education.); Espino v. Besteiro, 520 F. Supp. 905, 912 (S.D. Tex. 1981) (Cost of air-conditioned classroom for handicapped child minimal in relation to the amount of federal funds received by the school district and in relation to the district's total budget.); see also Yaris v. Special School Dist., 558 F. Supp. 545, 559 n.7 (E.D. Mo. 1983) ("[T]this court can not help but note that only one state in the country appropriates less funds than the State of Missouri for its educational system"), aff', 728 F.2d 1055, (8th Cir. 1984); Springdale School Dist. v. Grace, 494 F. Supp. 266, 272 (W.D. Ark. 1980) ("The school provides the nonhandicapped child an opportunity to learn the basics and to learn them well enough so that he might excel in his secondary school courses. But the . . . school does not turn every one of its students into academicians or professionals, or even successful secondary school students."), aff d, 656 F.2d 300 (8th Cir. 1981), vacated, 458 U.S. 1118 (1982), affd on rehearing, 693 F.2d 41 (8th Cir. 1982), cert. denied, 461 U.S. 927 (1983).

172. Much of the data collection and analysis for such guidelines has already taken place. See, e.g., Kakalik, supra note 2; MOORE, Walker \& Hollaṇd, supra note 3.

173. 29 U.S.C. $\$ 794$ (1982); see 34 C.F.R. § 104.12(c) (1984); 29 C.F.R. § 1613.704 (1984); Treadwell v. Alexander, 707 F.2d 473, 478 (11th Cir. 1983); Colin K. v. Schmidt, 536 F. Supp. 1375, 1388 (D.R.I. 1982), aff d, 715 F.2d 1 (1st Cir. 1983); see also 29 U.S.C. $\$ 794 \mathrm{a}(\mathrm{a})$ (1) (1982) (remedy for violation of section 504 should take into account reasonableness of cost of any necessary accommodations). 
child is determined by reference to what has been determined to be available for the nonhandicapped. Data for decisionmaking is highly individualized as it is not for other children, but entitlements for the handicapped are determined, in the final analysis, as part of an integrated process in which the needs and interests of the handicapped are coordinated with the needs and interests of others.

The program parity model, similarly, mediates the tension between the need-based framework for determining educational services for the handicapped and the merit-based framework of public education. Program parity recognizes that there are differences in need and ability that will justify different treatment, but compels evenhanded consideration of the interests of both. Differences in ability between the handicapped and nonhandicapped justify neither a lower level of attention, because of the inability of the handicapped to demonstrate the same levels of "innate" ability, nor compensation for the handicapped so extensive as to eliminate as far as educationally possible the effects of that handicap without regard to resource limitations. Instead, it requires school districts to offer services based on need to the handicapped on a par with services to others whose positions in the system will still be based on merit. Merit thus retains its established place in the public education system without compromising the need-based rationale for allocating resources to the handicapped.

The program parity model also addresses the tension between the centralized standards of the EAHCA and the tradition of local control of education by focusing federal intervention on the appropriate federal interest - ending unfair treatment of the handicapped in public education - while preserving the traditional role of state and local government for determining the appropriate content and quality of educational services. As I will explain in the next section of this article, recent constructions of the EAHCA have been insensitive to the real issue of federalism. Although the legal analysis in Board of Education $v$. Rowley is replete with invocations of the demands of federalism that matters of educational methodology should be left up to the individual states ${ }^{174}$ and that "due weight" should be given to state administrative proceedings ${ }^{175}$ - the educational benefit test set forth in that opinion is more offensive to basic federalism policies than the test I suggest.

\section{Program Parity and Educational Minimums}

Under Rowley, the EAHCA is satisfied so long as its procedural requirements are followed and the handicapped child is receiving "access to specialized instruction and related services which are individually designed to provide educational benefit to the handicapped child." 176 This standard, in interpreting the EAHCA to require a minimum level of education for the handicapped to be determined without respect to the benefits received by

174. 458 U.S. 176, 207 (1982).

175. Id. at 206.

176. Id. at 201. 
other children, forces judgments that (1) cannot meaningfully be made, and (2) should not be directed by the federal government.

Education is a purposive enterprise. Hence, any definition of a minimum can be formulated only by reference to the function education fulfills in achieving particular goals. Although there is agreement on certain general social, political, economic, and cultural goals in public education, ${ }^{177}$ consensus at the implementation level is impossible and probably undesirable. Communities have different needs and different priorities for their educational systems. Indeed, this diversity, which may reflect political differences of opinion and local variations in employment opportunities, is a primary reason for allocating control over education to state and local governments. ${ }^{178}$ Disagreement may exist about the desired level of educational services. Is the minimal goal of education respecting competence economic survival, getting a job, or getting a good job? Disagreement may also exist about the importance of certain types of learning: Should the goal of education be intellectual development or socialization skills? basic communication and computational skills or the ability to pursue and analyze abstract ideas? vocational training or preparation for higher education, science, or the liberal arts? excellence in one field or basic coverage of many? Teaching techniques and methods also vary, some schools preferring rote learning, others the process of free inquiry. Differences of opinion are particularly numerous in the relatively new field of special education. Unitary standards suggest that the subject of regulation is susceptible to having a uniform, best answer. Because of the diversity of educational priorities, theories, methodologies and needs, however, "certainty bespeaks ignorance." 179

Even if the goals of education could be determined, the role of education in achieving them is incremental. While minimums may have some signifcance with respect to certain basic goods and services such as housing and food, ${ }^{180}$ the nature of the education process makes the notion of minimums

177. These include the socialization of students within our political and cultural system, the acquisition of skills to enable them to be productive members of the economic system, and the development of social skills. See, e.g., Plyler v. Doe, 457 U.S. 202, 221 -22 (1982) (education "provides the basic tools by which individuals might lead economically productive lives to the benefit of us all ... . [it] has a fundamental role in maintaining the fabric of our society . . . . [and has a] pivotal role . . . in sustaining our political and cultural heritage"); Wisconsin v. Yoder, 406 U.S. 205,221 (1972) ("some degree of education is necessary to prepare citizens to participate effectively and intelligently in our open political system"); Brown v. Board of Educ., 347 U.S. 483, 493 (1954) (education is a "principal instrument in awakening the child to cultural values, in preparing him for later professional training, and in helping him to adjust normally to his environment."); Serrano v. Priest, 5 Cal. 3d 584, 604-06, 487 P.2d 1241, 1255-56, 96 Cal. Rptr. 601, 615-16 (1947) ("'F]irst, education is a major determinant of an individual's chances for economic and social success in our competitive society; second, education is a unique influence on a child's development as a citizen and his participation in political and community life.").

178. See supra notes $133-35$ and accompanying text

179. Kaden, supra note 165, at 1242. See San Antonio Indep. School Dist. v. Rodriguez, 411 U.S. 1, 42 (1972) ("Education, perhaps even more than welfare assistance, presents a myriad of intractable economic, social and even philosophical problems.") (citing Dandridge v. Williams, 397 U.S. $471,487(1970))$.

180. Michelman, Foreword: On Protecting the Poor Through the Fourteenth Amendment, 83 HaRv. L. Rev. 7 (1969). Cf. Karst, Serrano v. Priest's Inputs and Outputs, 38 Law \& Contemp. Probs. 333, 344 - 
hopelessly elusive. One can speak of more or less education, but once beyond zero education, not of minimums. A fifth grade education generally will be more beneficial than a fourth grade education and less beneficial than a sixth grade education, but it cannot be meaningfully said that one level or another is a minimum level of education. Thus it is that in making educational program decisions, school officials and school boards do not in any realistic sense engage in establishing minimums, but rather in evaluating better and worse alternatives. ${ }^{181}$ Although school finance theory presumes that states assume responsibility for a minimum level of education to be supplemented by higher service levels chosen and financed by the local system, ${ }^{182}$ school budgets are actually set "incrementally and with reference to the availability of funds for education." 183

Education is ordinarily valued also in relative terms. An important purpose of education is to prepare students for a competitive economy based on merit and achievement. Thus, the need for a student to learn advanced calculus, computer science, or fluent Spanish is determined in part by whether others whom a student will later face in the educational system or the job market have been trained in those subjects. For this reason, educational mini-

45 (1974). Even with respect to these basic human needs, the value attached to particular service levels is relative to what others receive. See Winter, Poverty, Economic Equality, and the Equal Protection Clause, 1972 Sup. CT. REv. 41, 71 ("no finite list of goods and services" that will remove poverty).

181. Cf. Miner, Estimates of Adequate School Spending by State Based on National Average Service Levels, 8 J. Educ. Fin. 316 (1983) (conceptualizing "adequate" level of education according to average national expenditures).

182. See Lujan v. Colorado State Bd. of Educ., 649 P.2d 1005, 1025 (Colo. 1982); Buse v. Smith, 74 Wis.2d 550, 570-74, 247 N.W.2d 141, $151-52$ (1976); Wise, supra note 67, at 308-09. School finance cases often involve the interpretation of state constitutional provisions designed to define the minimum level of acceptable education in that state. See Lujan, 649 P.2d at 1018 ("thorough and efficient" no mandate for equal expenditure); McDaniel v. Thomas, 248 Ga. 632, 285 S.E.2d 156, 165 (1981) (state constitution requires provision of "adequate education," which means basic education and not equality of opportunity); Hornbeck v. Somerset County Bd. of Educ., 295 Md. 597, 619 39, 458 A.2d 758, 770-80, (1983) ("thorough and efficient education" clause does not mandate equality of expenditure); Board of Educ. v. Nyquist, 57 N.Y.2d 27, 47, 439 N.E.2d 359, 453 N.Y.S.2d 643,653 (1982) (state constitution assures only "minimal [sic] acceptable facilities and services" in education and not equal facilities and services), appeal dismissed, 459 U.S. 1139 (1983); Seattle v. Washington, 90 Wash. 2d 476, $514-20,585$ P.2d 71, 93-96 (1978) (applying Wash. Const. art. 9, $\S \S 1,2$, to mandate state funding of a basic program of education for all children); Pauley v. Kelly, 255 S.E.2d 859, 878-79 (W. Va. 1979) ("thorough and efficient" education clause requires development of high quality statewide standards, something more than mere equality of funding to counties). But see Robinson v. Cahill, 62 N.J. 473, 513-14, 303 A.2d 273, 294 (1973) (applying the "thorough and efficient" education standard of the New Jersey Constitution to require equal educational opportunity).

183. Wise, supra note 67, at 314; see also A. WiSE, supra note 88 , at 145 ("In effect, educators are viewed as setting norms for all students at a level which will just exhaust available educational resources."); Karst, supra note 180 , at 344 .

In expressing the complexity of the notion of educational adequacy, Wise concludes that "adequacy is in the eye of several beholders and may be appraised formally or informally and against a uniform or flexible standard." Wise, supra note 67 , at 310 . He concludes that the concept of educational adequacy is in fact a redefinition of the problem of equal educational opportunity. Id. at 315 . For a critique of the similar concept of "functional literacy" as a description of minimum norms, see Levine, Functional Literacy: Fond Illusions and False Economics, 52 Harv. Educ. Rev. 249 (1982); see also Robinson v. Cahill, 62 N.J. 515, 303 A.2d 273, 295 (1973) (describing the constitutional mandate of a "thorough and efficient education" as a relative concept). 
mums are "significantly a function of the maximum."184 Moreover, on an individual level, it is clear that the value of education is derived from what the individual child himself is able to make of what education is provided. The emphasis on the equality of opportunity rather than educational achievement or results recognizes that children cannot be forced to learn, that they vary in motivation and receptivity to education, and that their academic rewards will depend in large part on the nature of their voluntary engagement with what is offered to them. ${ }^{185}$

Not only does the minimum educational benefit standard require judgments that cannot meaningfully be made, but it requires judgments that should not be directed by the federal government. Enforcing educational standards at a particular level, even if only a "minimum" level and even if only for the handicapped, removes from local and state government a function that is particularly critical to its authority over education. Moreover, it ignores the issue of fairness of treatment for a discrete, disadvantaged group - the handicapped - which is the more appropriate domain of federal intervention. ${ }^{186}$

The legislative history of the EAHCA is consistent with the view that the federal interest in education is comparative rather than absolute. Concern with fairness between the handicapped and the nonhandicapped pervades this history. ${ }^{187}$ Although there was a wide range of opinions expressed in Con-

184. Michelman, supra note 180 , at 58. Michelman, who urges the minimum protection view with respect to other human needs, recognizes that this view is especially problematic with respect to education. See id. at 19,47-59. See also Winter, supra note 180, at 71 .

185. The school environment may, in turn, have an effect in influencing the educational aspirations and motivations of its students. See Katz, Academic Motivation and Equal Educational Opportunity, 38 Harv. Educ. Rev. 57 (1968), reprinted in Equal Educational Opportunity at 60 (1969); Wilson, supra note 85, at 80-81, reprinted in EQUal. EDUCATIONAL OPPORTUNITY at 83-84; see also supra note 141 and accompanying text (importance of home life to success in school).

186. Ironically, because of the relativity of educational norms and the subjectivity of educational minimums, the Rowley "some benefit" approach used in Board of Educ. v. Rowley, 458 U.S. 176 (1982), may in some cases be used to compel school districts to provide to the handicapped educational services that are excessive and unfair to the nonhandicapped. This is all the more likely if Professor Wegner is correct in her analysis that a rigorous standard must be applied to the process of identifying a child's needs and appropriate educational program. See Wegner, supra note 161, at 18694; see also Zirkel, Building an Appropriate Education from Board of Education v. Rowley, 42 MD. L. REv. 466, 481-84, 487 (1983) (Rowley may be interpreted in some circumstances to set high substantive demands on school districts); Note, The Rowley Decision, supra note 11, at 703-04 (courts will interpret the Rowley standard in light of their own theories); Colley, supra note 11, at 152 (suggesting there might be a reverse discrimination problem under the EAHCA).

The some benefit test, as explained above, takes no explicit account of the cost of a program. If the standard is given real teeth, and cost factors are ignored, the nonhandicapped may be forced to bear a disproportionate share of the effects of resource scarcity. Placing a duty upon a school district to provide a full-time residential placement with a full range of round-the-clock educational stimulation may have a ruinous effect on its budget and on other educational programs while achieving only a de minimis benefit for the handicapped. See Stark, supra note 2, at 493; Adams Cent. School Dist. v. Deist, 215 Neb. 284, 285-87; 338 N.W.2d 591, 591-92 (1983), aff'g as modified, 214 Neb. 307,334 N.W. 2d 775 (1983), cert. denied, 104 S. Ct. 239 (1984). Thus, at the same time that the duty to provide "some benefit" may leave handicapped children at a marked disadvantage in asserting a claim for resources, it may impose a backbreaking obligation upon school districts attempting to serve a severely handicapped child for whom benefit is extraordinarily elusive.

187. See S. ReP. No. 168, 94th Cong., 1st Sess. 9, reprinted in 1975 U.S. Code Cong. \& Ad. News 1425,1433 ("This Nation has long embraced a philosophy that the right to a free appropriate public education is basic to equal opportunity. . . . It is contradictory to that philosophy when that right is 
gress at the time the EAHCA was passed, the focus on equal educational opportunity is impressive. Evidence in the legislative history that many handicapped children in the United States were being entirely excluded from education was emphasized by the Supreme Court in Board of Education $v$. Rowley to justify the minimum benefit standard. ${ }^{188}$ This concern for the total exclusion of handicapped children must be analyzed, however, in light of the fact that at the time, nonhandicapped children did have access to public education. It was this disparity that Congress sought to correct. This is not to say that Congress could not legitimately be concerned if it determined that no child was receiving a proper education, and undertake drastic measures to correct the situation, even assuming direct control over the nation's education system under its common power. Congress also may set out to improve the level or quality of public education in some particular way, as it has done through various federal aid-to-education programs. ${ }^{189}$ Indeed, Congress surely intended to improve the quality of education for the handicapped in passing the EAHCA. ${ }^{190}$ When Congress undertakes to identify a group that has been previously disadvantaged in receiving public education that is available to others, however, and requires that an "appropriate" education be provided to members of that group, the meaning of the requirement should be ascertained in light of the generally accepted federal interest in equal treatment for

not assured equally to all groups of people within the Nation. . . . It is this Committee's belief that Congress must take a more active role under its responsibility for equal protection of the laws to guarantee that handicapped children are provided equal educational opportunity.").

The Congressional Record also overflows with references to the goal of equal educational opportunity for the handicapped. See 121 Conc. Rec. 19,503 (1975) (remarks of Sen. Cranston) ("[The Act's] enactment will signify a new beginning and the broadening of equal opportunity for all our children."); id. at 37,410 (remarks of Sen. Randolph) ("The [EAHCA] promises handicapped children the educational opportunity that has long been considered the right of every other American child."); id. at 25,540 (remarks of Rep. Grassley) ("[h]andicapped children have always been slighted on equal educational opportunity.").

The House and Senate reports both contained language which linked services that were to be provided to the handicapped to services that were being provided to the nonhandicapped. See, e.g., S. REP. No. 168, 94th Cong., 1 st Sess. 12, reprinted in 1975 U.S. Code Cong. \& Ad. News 1425, 1436. The report stated:

The Committee points out in addition that a handicapped child has a right to receive all services normally provided a nonhandicapped child. . . . Thus, he or she has a right to physical education services, . . . transportation services and all other services . . . provided to all children within the school system, and a right to as many options in curricula as are available to all children.

Id.; H. R. REP. No. 332, 94th Cong., 1st Sess. 10 (1975) ("The committee would like to see that each handicapped child to the best of his or her ability be able to participate in extracurricular activities to the same extent as nonhandicapped children."); see also 34 C.F.R. $\$ \$ 300.305-.306$ (1984). For a more complete collection of statements relating to the Act's objectives of equal opportunity for handicapped children, see Note, Attack on the EHA supra note 161, at 194-96. Cf. Commonwealth v. School Comm. of Springfield, 382 Mass. 675-79, 417 N.E.2d 408, 414-15 (1981) (purpose of state law regarding education of the handicapped is to prevent denials of equal educational opportunity).

188. 458 U.S. $176,191-97$ (1982).

189. See, e.g., National Defense Education Act of 1958, 20 U.S.C. $\$ 401$ (omitted 1982 because programs have not been funded for a number of years); Education Consolidation and Improvement Act of 1981, 20 U.S.C. $\S \S 3801-3876$ (1982).

190. See, e.g., H.R. REP. No. 332, 94th Cong., 1st Sess. 10, 11 (1975) (describing unserved population of handicapped children); 121 Cong. Rec. H7148 (remarks of Rep. Brandemas) (need for federal government to act if substantial progress to be made in education for the handicapped). 
the disadvantaged, and in recognition of the relative nature of education. The alternative - a federal definition of the required level of services-embarks the federal government on an expedition outside the customary boundaries of federal intervention in education for which it is unsuited.

The minimum educational benefit standard has received some support in academic literature. ${ }^{191}$ In addition, the United States Supreme Court has appeared to rely upon a concept of educational minimums in two recent equal protection cases. These cases require further attention.

In San Antonio Independent School District $v$. Rodriguez, ${ }^{192}$ the Court implied that so long as every student had the opportunity for a "basic education," the state had no constitutional obligation to equalize that opportunity between school districts with varying taxing capacities. ${ }^{193}$ Despite this opinion's apparent support of the notion of educational minimums, ${ }^{194}$ Rodriguez did not actually decide whether a state is obligated to provide at least some minimal level of educational service. ${ }^{195}$ To the extent that the Court may have implied that some minimal level of education was required, this level seemed to refer to anything higher than "an absolute denial of educational opportunities."196 This rock bottom definition, which may be all that could be compelled by the United States Constitution, could hardly be adopted as a standard consistent with the ambitious goals of the EAHCA.

By speaking of the right of illegal alien children to a "basic education," the Court in Plyler v. Doe ${ }^{197}$ may also be viewed as having endorsed the concept of educational minimums. Plyler, however, is an equal protection case holding that illegal alien children should have access to the public education system. Insofar as the Court speaks at all of the level of services for illegal alien children in relation to those offered to other children, the suggestion is that these services should be equivalent. ${ }^{198}$

It is clear that much of the concern with judicial interference in education, expressed in Rodriguez and Plyler, is a concern about the courts assuming a legislative role. ${ }^{199}$ This concern is considerably less pertinent to an analysis of

191. See, e.g., Levinson, The Right to a Minimally Adequate Education for Learning Disabled Children, 12 VAL. U.L. REV. 253 (1978) (arguing for minimally adequate education for learning disabled children); McClung, Do Handicapped Children Have a Legal Right to Minimum Adequate Education?, 3 J. LEGAL EduC. 153,160 (1974). The minimum competency testing movement demonstrates the related belief that educational minimums can be defined. See McClung, Competency Testing Programs: Legal and Educational Issues, 47 FordhaM L. REv. 651, 698-701 (1979); Young, Legal Aspects of Minimum Competency Testing in the Schools, 16 LAND \& WATER L. REv. 561, 615-20 (1981); Logar, Minimum Competency Testing in Schools: Legislative Action and Judicial Review, 13 J.L. \& EDuc. 35 (1984).

192. 411 U.S. 1 (1972).

193. Id. at $36-37,49$.

194. See Richards, Equal Opporiunity and School Financing: Towards a Moral Theory of Constitutional Adjudication, 41 U. CHI. L. REv. 32, 63 (1973).

195. 411 U.S. at $36-37$.

196. Id. at 37 .

197. 457 U.S. $202,223,226$ (1982).

198. "If the State is to deny a discrete group of innocent children the free public education that it offers to other children residing within its borders, that denial must be justified by a showing that it furthers some substantial state interest." Plyler v. Doe, 457 U.S. 202, 230 (1982) (emphasis added). 199. See Rodriguez, 411 U.S. at 31 ; $c f$. A. Bickel, The Least Dangerous Branch $16-17$ (1962). 
what meaning should be given to federal legislation creating enforceable rights for certain individuals than it was in those cases responding to constitutional challenges to state education practices. It still raises an issue of federalism, however, insofar as the opportunity for judicial rulemaking under authority of federal legislation may enhance the risk of encroachment upon the prerogative of state and local government. A standard that requires setting a particular level of service, even a "minimum" or "adequate" level, engages a decisionmaker in establishing policy and defining norms for that service. This norm-setting assignment asks more of courts attempting to apply the EAHCA than would the task of ensuring fairness in educational programming between the handicapped and nonhandicapped; these latter efforts do not define educational norms, but rather discover and apply them.

This is not a point about how much power either the federal government or state and local governments should have. In fact, it has been forceably argued that an increased federal presence in education does not necessarily weaken local authority, and may instead strengthen it. ${ }^{200}$ It is, rather, a point about the nature and quality of the federal presence. ${ }^{201}$ A federal presence that extends to guaranteeing a particular, albeit "minimal," level of educational services to the handicapped may intrude in an activity best left in our federal system to state and local government, while failing to perform its intended federal function of protecting disadvantaged individuals vis a vis the majority.

200. See Cohen, Policy and Organization: The Impact of State and Federal Educational Policy on School Governance, 52 Harv. Educ. Rev. 474, 489 (1982).

201. See A. WISE, supra note 165 , at x-xi (1979) (the enforcement of particular educational standards creates a more intrusive, bureaucratic, and centralizing federal presence than the enforcement of equal educational opportunity); $c f$. Wise, Legal Challenges to Public School Finance, 82 SCHOOL REv. 1 , 20 (1973) ("If the state seriously develops a prescription for minimal educational outputs, it may well become a more important partner in education than many would like to see happen.")

The notion of federally imposed minimums should be rejected even as a supplement to the concept of program parity. For some handicapped children it may seem that a guarantee of a minimal level of education may be necessary in addition to a guarantee of "equal" treatment. See Note, Enforcing the Right, supra note 8, at 1126 n.146. A severely handicapped child, whose first-rate educational program-placement in a residential institution-can bear no quality cuts if she is to gain any benefit, will not require, however, the protection of the minimum educational benefit standard. The concept of program parity guarantees programs that yield a comparable opportunity to experience comparable educational benefit. For those children for whom the high price of a first-rate program cannot be scaled down or compromised under this principle, greater imagination might be shown in spreading the costs of that program widely throughout society. See Moore, Walker \& Holland, supra note 3, at 59-76. Currently, the level of funding from the federal government under the EAHCA does not vary depending upon the severity of the handicap or the cost of the child's educational program. See Barro, supra note 118, at 50-51; 20 U.S.C. $\$ 1411$ (1982). It is already common for other state agencies to assume some of the extraordinary costs associated with educating the handicapped, often through interagency agreements. See Moore, Walker \& Holland, supra note 3 , at 39-40. Jurisdictional disputes between state agencies often frustrate the authorization of programs for children with extraordinary needs. See, e.g., North v. District of Columbia Bd. of Educ., 471 F. Supp. 136, 141 (D.D.C. 1979); Parks v. Illinois Dep't of Mental Health, 110 Ill. App. 3d 184, 187-89, 441 N.E.2d 1209, 1212 (1982); Kerr Center Parents Ass'n v. Charles, 572 F. Supp. 448, 454-55 (D. Or. 1983). These kinds of disputes are discussed at length in Mooney \& Aronson, supra note 49, at 545-46. See also Stoppleworth, Mooney E Aronson Revisited: A Less Than Solomon-Like Solution to the Problem of Residential Placement of Handicapped Children, 15 ConN. L. REv. 757, 764 (1983); Leviton \& Shuger, Maryland's Exchangeable Children: A Critique of Maryland's System of Providing Services to Mentally Handicapped Children, 42 MD. L. REv. 823 (1983). 


\section{E. Program Parity and Cost-Benefit Analysis}

Because program parity admits the relevance of cost and requires comparisons of quality between unlike programs, there may frequently arise the question of whether it is appropriate to engage in any kind of cost-benefit analysis in order to determine whether a particular program is required. As an initial matter, it would seem that the EAHCA does not permit any calculations of relative value or cost-effectiveness. A statement made by one court, speaking of the expenditures that may be required to allow severely handicapped children to make only slight progress, is typical of judicial attitudes on this point: "The language and the legislative history of the Act simply do not entertain the possibility that some children may be untrainable."202 The conclusion that cost-effectiveness factors cannot enter into decisionmaking under the Act, however, bears closer analysis.

Cost-benefit calculations are of two types (at least). First, cost-benefit considerations could be used in choosing between alternative programs to achieve the same or similar results. This use of cost-effectiveness analysis, ${ }^{203}$ focusing on the choice of means for attaining given goals, surely should be acceptable in education, even commendable. If a placement in a child's home district can meet the child's needs as well as a placement outside the district and is less expensive, the district should not be required to arrange the outof-district placement for the child based upon the personal preference, whim, or convenience of the parents. Likewise, the school should not be required to invest in expensive experimental technology that has not demonstrated its effectiveness for a handicapped child. ${ }^{204}$

Other forms of cost-benefit analysis are more problematic. Consider the example of an aide who will increase, if only slightly, the likelihood that a mildly-retarded student could learn to read at an elementary level, but who can be afforded only at the expense of a classroom computer that could be profitably used to learn basic computer skills by twenty-five nonhandicapped children in a regular, third grade class. This aide may be justified under a cost-benefit analysis if the value to the child is greater than the expense of the aide. Alternatively, the aide may be said to be cost-beneficial if the benefit

202. Kruelle v. New Castle County School Dist., 642 F.2d 687, 695 (3d Cir. 1981); see also Stark, supra note 2 , at $497-98$.

203. For a discussion of the difference between cost-benefit and cost-effectiveness analysis, see Bangser, An Inherent Role for Cost-Benefit Analysis in Judicial Review of Agency Decisions: A New Perspective on OSHA Rulemaking, 10 B.C. Envtl. AfF. L. REv. 365, 405 (1982).

An excellent comparison of the various legislative models of cost-benefit analysis, including the cost-effective and strict cost-benefit approaches, is given in Rodgers, Benefits, Costs and Risks: Oversight of Health and Environmental Decisionmaking, 4 HARV. ENVTL. L. REV. 191, 201-14 (1980). Rodgers also discusses an intermediate form of analysis which he calls the "cost-sensitive approach." Under this approach, decisionmakers are given authority to make decisions in consideration of such factors as feasibility and economic practicability. Id. at 206-10. Because this form of analysis permits costefficiency calculations, I refer to it here as cost-efficiency analysis.

204. It is this kind of calculation that Bruce Ackerman may have had in mind in suggesting a modified cost-benefit analysis in choosing between various contestable alternatives that fall within the acceptable range of equivalent sacrifices. B. ACKERmaN, supra note 13, at 249-50. 
received by the handicapped children is greater than the value of a computer to the nonhandicapped children.

The first determination, whether the benefit justifies the cost on its own terms, would seem an appropriate calculation in designing education programs. ${ }^{205}$ Why should programs be financed by the school system when the expected benefit is not greater than the cost? This analysis must be conducted carefully, however, for judgments of value can be extremely subjective and can easily incorporate the biases upon which education was denied for so long to handicapped children. Will value be measured only in terms of future economic productivity? Or will it take proper account of the value to the individual of self-growth and dignity or of self-reliance? Although it is often argued that education of the handicapped is ultimately cost-effective because otherwise the handicapped children will become more dependent upon public assistance, ${ }^{206}$ such a utilitarian or efficiency analysis, in focusing on economic factors, has some potential for corrupting the task. ${ }^{207}$

The second type of cost-benefit calculation is considerably more suspect. In asking whether some children can use resources more productively than others, decisionmakers may well value learning by the handicapped less highly than learning by the nonhandicapped. By making the benefits of learning relevant and by allowing comparisons between the benefits experienced by different children, this analysis treats some human pleasures as replaceable by the pleasures of others. This is unacceptable. As H. L. A. Hart explains, for "a single individual to sacrifice a present satisfaction or pleasure for a greater satisfaction later" is prudent and virtuous, but to require one individual to sacrifice in order for another to gain, "treats the division between persons as of no more moral significance than the division between times which separates one individual's earlier pleasure from his later pleasures, as if individuals were mere parts of a single persisting entity." ${ }^{208}$ Thus, while efficiency analysis to evaluate whether a service for a handicapped child is "worth it" should

205. This type of cost-benefit analysis was approved in Roncker v. Walter, 700 F.2d 1058 (6th Cir.), cert. denied, $104 \mathrm{~S}$. Ct. 196 (1983), when the court pointed out that "some handicapped children simply must be educated in segregated facilities . . . because any marginal benefits received from mainstreaming are far outweighed by the benefits gained from services which would not feasibly be provided in the non-segregated setting . . . ." Id. at 1063; see also MOORE, WALKer \& Holland, supra note 3 , at $37-38,40-43$ (recommending modification of special education program and state reimbursement policies to encourage more cost-effective service practices).

206. See S. ReP. No. 168, 94th Cong., 1st Sess. 9, reprinted in 1975 U.S. Code Cong. \& AD. News 1425, 1433; 121 CoNG. REC. 19,492 (1975) (remarks of Sen. Williams) ("providing appropriate educational services now means that many of these individuals will be able to become a contributing part of our society, and they will not have to depend on subsistence payments from public funds.") Note, The Education for All Handicapped Children Act: Opening the Schoolhouse Door, 6 N.Y.U. REv. L. \& Soc. Change 43, 58 (1976); Moore, Walker \& Holland, supra note 3, at 33-34; see also In re Downey, 72 Misc. 2d 772, 340 N.Y.S.2d 687, 690 (1973) (cost of education and transportation of handicapped child minimal in light of cost of institutionalization and value of loss of potentially productive adult); Murdock, Civil Rights of the Mentally Retarded: Some Critical Issues, 48 Notre Dame Law. 133, 164-65 (1972); Comment, Toward a Legal Theory of the Right to Education of the Mentally Retarded, 34 Онго Sт. L.J. 554, 559-60 (1973); Levinson, supra note 191, at 271-72 (disproportionate number of learning disabled among high school dropouts, juvenile delinquents, and criminals).

207. See R. Dworkin, Taking Rights Seriously 237, 275 (1977).

208. Hart, Between Utility and Rights, 79 Colum. L. Rev. 828, 831 (1979). 
be allowed only if engaged in very carefully, cost-benefit comparisons between services for the handicapped and the nonhandicapped should be avoided altogether.

The program parity approach to the cost issue avoids some of the pitfalls of a cost-efficiency analysis by assuming that the educational goals of handicapped and nonhandicapped children are equally worthy. Under progam parity, goals set on the basis of the needs and abilities of each child are not compared or evaluated in light of other children's goals, as would be required under a strict cost-benefit analysis. Instead, they are treated as givens entitled to the same respect and the same degree of fulfillment.

\section{V}

\section{The Process of Educational Decisionmaking}

As noted above and discussed by a number of other authors in this symposium issue, the EAHCA specifies detailed procedures to be followed in reviewing whether handicapped children have received the educational services to which they are entitled. ${ }^{209}$ The purpose of this section is not to review or analyze these procedures fully-the basic model is assumed to be fair and reasonable and the reader is assumed to be familiar with the process-but to suggest implications that a program parity model might have in clarifying and improving the process so as to promote fair resolution of cases with difficult cost issues.

\section{A. Problems in Judicial Procedure Under the EAHCA}

There are two process issues which bear on consideration of cost as a factor under the Act: 1) the allocation of burdens of proof on the various substantive issues that may arise (including the issue of cost); and 2) the level of deference, if any, that should be given to decisions made at the different levels of local and state authority under the Act.

Both the burden of proof and the judicial deference issues can be particularly important when decisionmaking involves difficult and close factual determinations. ${ }^{210}$ Decisionmaking under the EAHCA entails such determinations. The assessment of potential educational needs and the design of an appropriate educational program often raise close questions of educational methodology and philosophy and difficult predictions about the success of techniques and materials on the future development of a child. ${ }^{211}$ If program parity is pursued, the issue of whether resources have been fairly allocated also raises difficult issues of educational quality and program comparison.

The EAHCA is not specific about where the burdens of proof lie on the

209. 20 U.S.C. $\S 1415$ (1982).

210. See Texas Dep't of Community Affairs v. Burdine, 450 U.S. 248, 255 n.8 (1981).

211. See supra note 78; $c$. Addington v. Texas, 441 U.S. 418, 430 (1979) (psychiatric assessments based on nuances, uncertainties, and subjective factors). 
various issues arising under the Act, ${ }^{212}$ and courts have not been consistent in allocating these burdens. As to the most litigated issue under the EAHCA of whether an offered program is "appropriate," a number of courts have put the burden of proof on school districts to show that the educational services offered to a child are appropriate. ${ }^{213} \mathrm{~A}$ few courts have put the burden of proof on the plaintiffs who are challenging the educational program offered to the handicapped child to show that the program is inappropriate. ${ }^{214}$ Others put the burden of persuasion squarely on the party seeking a change in placement, ${ }^{215}$ with some courts appearing to set the burden by reference to a decision made at one or another particular procedural level. ${ }^{216}$ Although the

212. See Lang v. Braintree School Comm., 545 F. Supp. 1221,1226 (D. Mass. 1982).

213. See, e.g., Grymes v. Madden, 672 F.2d 321, 322 (3d. Cir. 1982); Davis v. District of Columbia Bd. of Educ., 530 F. Supp. 1209, $1211-12$ (D.D.C. 1982) ("It is the school district's burden of proof to show that its proposal is indeed an appropriate one."); Lang v. Braintree School Comm., 545 F. Supp. 1221, 1228 (D. Mass. 1982) (school district must show appropriateness of IEP by preponderance of the evidence); In re Richard H., 1980-81 EdUC. HANDICAPPED L. REP. (CRR) 502:203, :204 (Ga. SEA 1980); Scott B. v. Harlingen Consol. Indep. School Dist., 1982-83 Educ. HandiCAPPED L. REP. (CRR) 504:344, :349 (Tex. SEA 1983) (interpreting Board of Educ. v. Rowley, 458 U.S. 176 (1982), as placing burden on school district).

The burden of proof has also been placed on the school district to demonstrate that the program offered is the least restrictive alternative. See Roncker v. Walter, 700 F.2d 1058, 1061 (6th Cir.), cert. denied, 104 S. Ct. 196 (1983) (school district must prove that its proposed placement affords maximum appropriate contact with nonhandicapped). This requirement has also been placed on state education agencies. See Mallory v. Drake, 616 S.W.2d 124, 126 (Mo. App. 1981).; cf. Larry P. v. Riles, No. 80-4027, slip op. (9th Cir. Jan. 23, 1984) (available on LEXIS, Genfed library, Cir. file) (state has burden of proof under EAHCA in showing test and evaluation procedures free of racial and cultural bias).

214. See, e.g., Bales v. Clarke, 523 F. Supp. 1366, 1370 (E.D. Va. 1981) ("Plaintiff bears the burden of establishing that the Regional School is inappropriate, that no other State facility is appropriate, and that Accotink Academy is appropriate."); Cothern v. Mallory, 565 F. Supp. 701, 705-08 (W.D. Mo. 1983) (parents failed to meet burden of proof on issue of inappropriateness of education or on issue of lack of compliance by school district with due process procedures). Tatro v. Texas, 703 F.2d 823, 830 (5th Cir. 1983) (school district has burden of showing IEP inappropriate), affd in part, rev'd in part sub nom. Irving Indep. School Dist.v. Tatro, 104 S. Ct. 3371 (1984); see also Zirkel, supra note 186, at 485 \& nn.133-34. Cf. Fitz v. Intermediate Unit Number 29, 43 Pa. Commw. 370, 374,403 A.2d 138, 140 (1979) (under state law, burden on petitioners to show inappropriateness of program).

215. Doe v. Brookline School Comm., 722 F.2d 910,917 (1st Cir. 1983) (party wishing to depart from status quo should make motion for preliminary injunction). Some courts, in determining whether this burden is met, may be influenced by whether the child has made any progress in his current placement. E.g., Norris v. Massachusetts Dep't of Educ., 529 F. Supp. 759, 767 (D. Mass. 1981); Gladys J. v. Pearland Indep. School Dist., 520 F. Supp. 869; 877-78 (S.D. Tex. 1981); San Francisco Unified School Dist. v. State, 131 Cal. App. 3d 54, 71, 182 Cal. Rptr. 525, 535-36 (1982); see Note, Board of Education v. Rowley, supra note 8, at 299 n.116. In the state of Washington, "academic progress" apparently will give rise to a presumption that a free and appropriate education has been provided by the school district. See Note, Attack on the EHA, supra note 161, at 207-08.

It has also been suggested that the Act places the burden of persuasion on the party which seeks to remove the child from the regular educational environment. Note, Enforcing the Right, supra note 8 , at 1119, 1122; Colley, supra note 118, at 155 (1981) (burden on party advocating most restrictive environment).

216. See, e.g., Tatro v. Texas, 703 F.2d 823, 830 (5th Cir. 1983), aff'd in part rev'd in part sub nom. Irving Indep. School Dist. v. Tatro, 104 S. Ct. 3371 (1984) (party attacking IEP bears burden to show inappropriateness); McKenzie v. Jefferson, 566 F. Supp. 404, 406 (D.D.C. 1983) (plaintiffs bear burden of establishing by a preponderance of evidence that local hearing officer's determination should be set aside); Pires v. Pennsylvania Dep't of Educ., $78 \mathrm{~Pa}$. Commw. 127, 135, 467 A.2d 79, 82 (1983) (order of state secretary of education must be upheld unless shown to be unsupported by substantial evidence); Johnston v. Ann Arbor Pub. Schools, 569 F. Supp. 1502 (E.D. Mich. 1983) (deference to 
allocation of the burden of proof appears to make a difference in the outcome of a case, ${ }^{217}$ the burden of proof issue is sometimes ignored or finessed.218

The extent to which judicial deference should be given to state or local decisionmaking is only somewhat more clearly resolved. The Supreme Court, in Board of Education $v$. Rowley, acknowledging both the lack of expertise and experience by courts and the "primacy of States in the field of education," 219 held that once a court determines that the requirements of the EAHCA have been met, questions of educational theory and methods are for resolution by the states. ${ }^{220}$ There are some reasons for reserving deference only to local educators involved in formulating the individualized education plan (IEP). These professionals are comparable to the decisionmakers in Youngberg $v$. Romeo ${ }^{221}$ and Parham v. J.R., ${ }^{222}$ to whom a presumption of correctness is owed when individuals facing institutionalization claim constitutional violations of their due process rights. More so than state review officers, the professionals responsible for drafting the IEP's are the experts who are closest to the facts of the individual case. Moreover, it is the local educational agency that receives the bulk of federal funds and to whom the job of providing educational services actually falls. ${ }^{223}$ It might also make sense to extend deference to the decision of the local hearing officer who has heard all of the witnesses as well as the arguments of the parties. ${ }^{224}$ Nevertheless, the EAHCA places ultimate responsibility for compliance on the state, ${ }^{225}$ and the state is to provide a mechanism for de novo review. ${ }^{226}$ Thus, under Rowley judicial defer-

findings of state officials); Cohen v. School Bd., 450 So.2d 1238, 1241 (Fla. App. 1984) (decision of hearing officer must be upheld unless no substantial evidence).

217. Compare, e.g., Bales v. Clarke, 523 F. Supp. 1366 (E.D. Va. 1981) (burden of proof put on parents, who did not meet it) and Cothern v. Mallory, 585 F. Supp. 701 (W.D. Mo. 1983) (parents failed to meet burden) with Grymes v. Madden, 672 F.2d 321 (3d Cir. 1982) (burden put on school district, which did not meet it) and Mallory v. Drake, 616 S.W.2d 124 (Mo. 1981) (school district unable to meet burden). But see Lang v. Braintree School Comm., 545 F. Supp. 1221 (D. Mass. 1982) (school district meets its burden); McKenzie v. Jefferson, 566 F. Supp. 404 (D.D.C. 1983) (school district meets its burden); Pires v. Pennsylvania Dep't of Educ., 78 Pa. Commw. 127, 467 A.2d 79 (1983) (parents meet burden).

218. See, e.g., Colin K. v. Schmidt, 536 F. Supp. 1375, 1386-87 (D.R.I. 1982), affd, 715 F.2d 1 (1 st Cir. 1983) (proposed IEP "clearly inadequate" and evidence of disabilities "not sufficiently controverted by defendants' witnesses").

219.458 U.S. 176, 208 (1982).

220. Id. at 207-08.

221. 457 U.S. 307 (1982).

222. 442 U.S. 584 (1979).

223. 20 U.S.C. $\S \S 1411$ (b), (d), 1420 (a) (1982); see Note, supra note 206 , at 49 . In the state of Washington, school districts are aided at the state review level by a presumption affecting the burden of proof if their IEP procedures are correct and their experts are qualified and in agreement. See Note, Attack on the EHA, supra note 161 at 204-06.

224. See 34 C.F.R. \$\$ 300.506-.508(1984). A few cases have followed this approach. See McKenzie v. Jefferson, 566 F. Supp. 404, 406 (D.D.C. 1983); Cohen v. School Bd., 450 So. 2d 1238, 1241 (Fla. App. 1984).

225. 20 U.S.C. \$§1412(1), (6), 1414 (d) (1982); 34 C.F.R. $\$ \S 300.134, .136, .600$ (1984); see also Yaris v. Special School Dist., 728 F.2d 1055, 1057 (8th Cir. 1984); Kruelle v. New Castle County School Dist., 642 F.2d 687, 696-98 (3d Cir. 1981); Kerr Center Parents Ass'n v. Charles, 572 F. Supp. 448, 458 (D. Or. 1983); North v. District of Columbia Bd. of Educ., 471 F. Supp. 136, 139-40 (D.D.C. 1979).

226. 20 U.S.C. $\S 1415(\mathrm{~b})(2)$, (c) (1982). 
ence is owed to the final outcome of the state review process. ${ }^{227}$

It is less clear whether deference is required on all issues or whether, as Judith Wegner suggests, deference is appropriate only as to matters of judgment about educational methodology, leaving the courts broad review power over questions of needs assessment and overall program effectiveness. ${ }^{228}$ In providing that " $[t]$ he primary responsibility for formulating the education to be accorded a handicapped child, and for choosing the educational method most suitable to the child's needs, was left by the Act to state and local educational agencies . . ."229 and that "due weight" should be given to the results of the state administrative proceedings, ${ }^{230}$ the Rowley decision would seem to require deference on all issues. This view would conform to the Youngberg and Parham holdings that judicial review be limited to ensuring that professional judgment was in fact exercised. ${ }^{231}$ On the other hand, in its recent decision in Irving Independent School District $v$. Tatro, ${ }^{232}$ upholding an interpretation of the EAHCA to require clean intermittent catheterization for a spina bifida child as a "related service" under the Act, the Court, citing Rowley, noted the need for judicial review of the handicapped child's IEP to ensure that it conforms to the requirements of the EAHCA.233

Because the issues of burden of proof and judicial deference are critical ones, they require a clearer and more coherent resolution. I will reexamine these issues in the next section in light of the concept of program parity. This reexamination will focus primarily on local, rather than state, decisionmaking, for as a practical matter, how decisions by local school districts are treated will have the most significant impact upon how resources are allocated to handicapped children.

\section{B. The Special Efforts Approach: A Program Parity Solution}

It seems unlikely that Congress intended to reverse the neglect of handicapped children in public education by a set of procedures which leave up to the parents of those children the task of demonstrating that educational deci-

227. 458 U.S. at 206.

228. See Wegner, supra note 161 , at 186-90.

229. Rowley, 458 U.S. at 207.

230. 458 U.S. at 206.

231. Youngberg v. Romeo, 457 U.S. 307, 321 (1982); Parham v. J.R., 442 U.S. 584, 606-16 (1979); see Monahan v. Nebraska, 687 F.2d 1164, 1171 (8th Cir. 1982) (decisions of state officials entitled to presumption of validity if professional judgment exercised).

232. 104 S. Ct. 3371 (1984).

233. Id. at 3376 n.6. Several courts before Tatro, especially in the First Circuit, adopted this interpretation. See Doe v. Anrig, 692 F.2d 800, 806 (1 st Cir. 1982) (distinguishing between questions of educational policy, as to which deference is appropriate, and factual issues of effect of handicap on child's ability to benefit from an educational setting, as to which it is not); Abrahamson v. Hershman, 701 F.2d 223, 230 (1 st Cir. 1983) (issues of whether particular program would serve handicapped child's needs and whether particular placement was "educational" within the scope of the Act were not matters of educational policy on which district court must defer to state administrative proceedings); Colin K. v. Schmidt, 536 F. Supp. 1375, 1385 (D.R.I. 1982) (court's role in EAHCA proceedings is to assess evidence independently), aff', 715 F.2d 1 (1st Cir. 1983). But see Karl v. Board of Educ., 736 F.2d 873, 877 (2d Cir. 1984) (courts must defer to state authorities on suitability of educational program). 
sions by state and/or local educational agencies are inappropriate, especially if the procedures require deference to those agencies on all matters of educational theory, practice, or methodology. It also seems unlikely, however, that Congress intended to run roughshod over the tradition and practice of local and state decisionmaking or the custom of deference to professional decisionmakers in education. An ideal resolution of these issues would reconcile the affirmative goals of the EAHCA with the values and interests threatened by a single-minded adherence to these goals.

As an initial matter, it would seem that the burden of persuasion on whether an educational program offered to a handicapped child is appropriate (or otherwise meets the affirmative requirements of the EAHCA) should fall upon the defendant educational agency. Under the EAHCA, the school system is required to determine an appropriate educational program pursuant to detailed, specified procedures. ${ }^{234}$ Because of this duty, the school district should have knowledge of the relevant facts upon which the decisions were made, as well as expertise about the issues, and superior access to the information. The school district is thus the most appropriate party to bear the burden on these issues. ${ }^{235}$

If the program parity approach is followed, it is not so clear who should bear the burden on the issue of parity. Nor is it clear whether, in determining if the school district's burden is met, deference should be accorded to school districts as to resource allocation decisions that may underlie the choice of an educational program. On the one hand, the legitimate business of public schools could be severely burdened if they had to meet a high burden of proof on every decision challenged for unfair resource allocation. On the other hand, the tradition of disregard of the handicapped in public schools suggests that without an effective check, these judgments will not give adequate recognition to the needs and interests of handicapped children. School districts can easily frustrate the policies of the EAHCA if they need not justify a placement decision, or if a minimal articulation of a rational basis will suffice.

To resolve this dilemma it is necessary to identify the factor that would justify a burden of proof rule either on policy grounds or because of its probative value. On both counts, the factor that seems most pertinent to whether a school district should be required to prove program parity is the degree of good faith or the level of commitment the district has demonstrated to the handicapped in its educational programs generally. This factor, which could be measured by a "special efforts" standard, has probative value and also provides a policy reason for allocating the burden of proof. If a school district has made special efforts on behalf of the handicapped, it would seem less likely that the district has disadvantaged a particular handicapped child with respect to others, and it would seem more fair, as a matter of policy, to place

234. 20 U.S.C. $\$ 1415$ (b)(1)(A) (1982).

235. Cf. Allen, Presumption, Inferences and Burden of Proof in Federal Civil Actions-An Anatomy of Unnecessary Ambiguity and a Proposal for Reform, 76 Nw. U.L. REv. 892, 899 (1982) (burdens of persuasion on issues "peculiarly within the knowledge" of a party frequently allocated to that party). 
the risks of error upon a challenger to the school district's decision. On the other hand, if a school district has not made special efforts on behalf of the handicapped, there is some reason to assume that the district has not acted appropriately in a particular case, and it would be preferable on policy grounds to place the risks of error upon the district. Thus, whether the question of unequal or unfair treatment of a handicapped child is an affirmative defense to be proved by the school district or an element of the prima facie case to be proved by the parents of the child would turn upon the external criterion of whether the district has made "special efforts" toward educating the handicapped. If the district wants to benefit from the procedural advantages that accrue, it must first establish that special efforts have been made.

The same standard, though not helpful in resolving the question whether deference should be given to the outcome of the state hearing process, could also be used to determine whether to give deference to the programming decision of a school district. Deference to the professional educator in a decision that might have been influenced by cost considerations ${ }^{236}$ should depend upon whether the school has demonstrated the level of commitment that warrants the assumption that those decisions have been made in good faith.

A rule that uses "special efforts" or some other measure of good faith as a basis upon which to allocate the burden of proof or to determine whether to give deference to the school district on certain issues would respect both the goals of the EAHCA and the potentially disruptive effects the EAHCA might have upon an educational system. It also provides an additional means for promoting a fair allocation of resources between the handicapped and the nonhandicapped. In requiring school districts that assert cost as a defense to claims for educational services by the handicapped to account for the relative assignment of resource shortfall between the handicapped and nonhandicapped, procedural weight will be given to actions of school districts that have some probative value as to the district's compliance and that permit a fair policy judgment on where the risks of error should fall. When the issue is raised as to whether something less than a first-rate program for the handicapped is justified, a showing of special efforts by a school district would be an appropriate basis upon which to excuse the district from the added burden of persuasion on the issue of whether the effects of resource limitations were being made to fall disproportionately upon the handicapped.

The special efforts standard is not offered as a test of substantive compliance with the EAHCA. Rather, it is a means of measuring the district's good faith, commitment, or intent, so as to effect the appropriate allocation of the parties' burdens of proof. This intent is not an element of the merits of the case itself but, instead, a factor in allocating the procedural burdens.

236. The question will arise under this standard whether a decision was in fact influenced by cost considerations, or whether it was an entirely professional judgment. I propose that where any colorable claim can be made that cost factors influenced the decision, the special efforts standard would come into play to determine whether the decision was presumptively a valid professional judgment. 
The special efforts standard is analogous in the burden-shifting features of Title VII employment discrimination law and the Voting Rights Act. Under Title VII, ${ }^{237}$ demonstration of a discriminatory pattern or practice of unlawful employment discrimination will give rise to a presumption that individual class members, who otherwise bear the burden of demonstrating unlawful discrimination, ${ }^{238}$ have been the victims of discrimination. ${ }^{239}$ The burden of persuasion then shifts to the defendant to prove that those individuals were not in fact victims of unlawful discrimination. ${ }^{240}$

Section 4 of the Voting Rights Act ${ }^{241}$ similarly uses a threshold test to set the burdens of the parties. The statute provides an objective standard by which jurisdictions with a history of racial discrimination in voting are identified. If this standard is met, a voting district will have to obtain preclearance for change in a standard practice or procedure with respect to voting under section 5 of the Act. ${ }^{242}$ External criteria are thus used as a measure of probability of noncompliance or lack of good faith in order to impose a burden on districts to which they would not otherwise be subject. ${ }^{243}$

An approach to the burden of proof issue consistent with a special efforts approach was followed by one court in Lang v. Braintree School Committee. ${ }^{244}$ In Lang, the school district failed to comply with the procedural requirements of the EAHCA by not including the parents in the IEP planning process; on this basis, the court stated that "the burden must rest with the [defendant state and local educational agencies] to show, by a preponderance of the evidence, that Braintree's IEP provides [the child] with a 'free and appropriate public education." "245 Although no reasoning was given for this conclusion, and defendants in that case were able to meet the burden imposed upon them, the case exemplifies the use of an external criterion (compliance with mandated procedures) which are not legally relevant to the merits of the particular claim (whether the IEP provided a free and appropriate education) as a basis for allocating the burden of proof to a particular party. This approach takes account of policies ordinarily underlying the allocation of burdens of proof. The failure of the state and local educational agencies to comply with the clear, procedural requirements of the EAHCA reflects on the probability of the defendants acting properly in other regards under the EAHCA. This

237. Title VII of the Civil Rights Act of 1964, 42 U.S.C. $\S 2000$ e (1982).

238. United States Postal Serv. Bd. of Governors v. Aikens, 103 S. Ct. 1478 (1983); McDonnell Douglas Corp. v. Green, 411 U.S. 792, 802 (1973). Proof of a pattern and practice of discrimination will also justify class relief under Title VII, Franks v. Bowman Transp. Co., 424 U. S. 747 (1976), for which there is no analogy under the EAHCA.

239. Franks v. Bowman Transp. Co., 424 U.S. 747, 772 (1976); Cooper v. Federal Reserve Bank of Richmond, 104 S. Ct. 2794, 2799-2800 (1984).

240. Franks v. Bowman Transp. Co., 424 U.S. 747, 772 (1976).

241. 42 U.S.C. $\$ 1973$ b (1982).

242. Id. \$ $1973 \mathrm{c}$.

243. These external criteria are to be distinguished from the evidence of discriminatory effect of a voting practice which may be used to prove that discrimination was intentional. See Blumstein, supra note 83, at 649-50, 658-61; Rogers v. Lodge, 458 U.S. 613 (1982).

244. 545 F. Supp. 1221 (D. Mass. 1982).

245. Id at 1228 . 
failure further suggests where, as a matter of policy, one might wish the risks of error to fall. Procedural defects could be a basis in addition to "special efforts," upon which to allocate the burden of proof on other issues as well, such as whether program parity has been achieved, or whether a "professional judgment" was influenced by resource considerations. ${ }^{246}$

Measuring special efforts, like measuring educational quality, would be difficult, and would depend upon rough measurements or approximations. Nevertheless, some lessons can be drawn from attempts to make similar judgments in other areas of law. Regulations promulgated under the Urban Mass Transit Act (UMTA), for example, define "special efforts" that are required in the planning and design of mass transportation facilities and services so that mass transportation can be effectively utilized by elderly and handicapped persons. ${ }^{247}$ While the proposal I make in this paper is aimed at allocating procedural burdens rather than at determining compliance with the nondiscrimination provisions of a federal funding statute, UMTA regulations offer a few examples of special efforts and thus demonstrate how such a standard might be defined.

One illustration in the UMTA regulations defines a numerical percentage standard; the transit district satisfies the special efforts standard if it uses at least 3.5 percent of the financial assistance available under the UMTA for programs to serve wheelchair users and semiambulatory handicapped persons. ${ }^{248}$ A similar percentage standard might be developed to measure the level of commitment by a school district to the handicapped. Under this standard, the percentage of the school district budget committed to services for the handicapped could be compared to the average percentages of other school districts, with an adjustment for differences in costs or needs by region, size of district, or other factors. ${ }^{249}$ Quantification would be complicated due to local and state differences in methods of accounting and difficulties in determining how to allocate the costs of resources shared by both handicapped and nonhandicapped children. Nonetheless, records are kept so that it is now possible to accumulate statistics on the cost of educating the handicapped;250 voluntary guidelines could be established which would enable school districts to check their level of commitment against national norms.

246. One student writer suggested in a 1979 note that a school's adherence to the procedural requirements should affect the weight given to its assertions on other legal issues. Note, Enforcing the Right, supra note 8, at 1111 -13; see also Haggerty \& Sacks, supra note 158, at 993 (urging that failure to identify handicapping conditions would give rise to a rebuttable presumption of the inadequacy of the services offered by the school). But of. Davis v. Scherer, 104 S. Ct. 3012, 3019-20 \& n. 12 (1984) (failure of defendant state official to follow state administrative regulations not relevant to whether qualified immunity for violation of plaintiff's constitutional rights was forfeited).

247. 49 U.S.C. $\$ 1612$ (1982); 49 C.F.R. $\S 27.77$ (1984).

248. 49 C.F.R. pt. 27, subpt. D, app. A(1) (1984).

249. See generally Kakalik, supra note 2; Miner, supra note 181, at 321-25.

250. See generally Kakalik, supra note 2; Moore, Walker \& Holland, supra note 3; Jordan \& Stultz, supra note 162 . This task is complicated, of course, by differences in accounting systems, size and density of local school districts, cost of living factors, definitions and classifications of handicapping conditions, price differences within states, and other factors. See, Moore, Walker \& Holland, supra note 3 , at $\mathbf{4 3 - 5 8}$. 
The objection might be raised that a single numerical percentage standard would allow a school district's commitment to one group of handicapped children to camouflage its neglect of another group of handicapped children. For this reason, it might be advisable to develop separate percentage standards for different classifications of handicapped children. Alternatively, parents of a handicapped child who show a substantial disparity in commitment among the different groups of handicapped children served by the district could be given the benefit of a rebuttable presumption that resources have been unfairly allocated.

UMTA regulations also offer performance standards as an alternative measure of special efforts. For example, one UMTA standard measures performance by the purchase of equipment for use by the handicapped. ${ }^{251}$ This standard helps to address the equity problems between categories of handicapped persons. Service unit or performance standards, measured in units of special classes, extra personnel, and other resources, could be used in special education to measure the special efforts made by the district to serve handicapped children. ${ }^{252}$

The special efforts approach adds an additional level of fact-finding to the review of local and state educational agency decisionmaking, inviting the criticism that this scheme will make due process under the EAHCA, which is already too legalistic, ${ }^{253}$ even more burdensome. The additional factual issues also may open up the hearing to matters well beyond the individual whose educational program is at stake and to whom the issues of the hearing are ordinarily restricted. These are legitimate concerns, but not fatal ones. The data called for under either percentage or performance standards are the same type of data districts would need to determine for themselves whether educational programming decisions for handicapped children strike a fair balance between the needs of those children and the needs of others. Numerical spending standards and performance standards developed at the federal level could be useful to districts for evaluating their own priorities.

A special efforts standard affecting the allocation of burdens of proof and whether deference is given to local decisionmakers is consistent with the overall approach suggested by the program parity model. Program parity sets the focus on proportional quality. Like the special efforts standard, it puts alternative programs for the handicapped in perspective, helping to ensure that the interests of the handicapped are being taken into account within the context of the needs and interests of the public education system.

251. "Purchase of only wheelchair-accessible new fixed route equipment until one-half of the Heet is accessible. . . ." 49 C.F.R. pt. 27, subpt. D, app. A(2) (1984).

252. See KAKALIK, supra note 2 (study breaking down educational service units according to type of handicap and such factors as age of student, experience and educational level of teacher, instructional time, type of personnel, and others).

253. See Neal \& Kirp, supra note 72. 


\section{Conclusion}

The future of special education suffers from the lack of a firm consensus on the nature and extent of the public obligation toward the handicapped. This lack of consensus is particularly troubling as resources available to public education continue to shrink in relation to the demand for them, and as pressures mount upon an education system increasingly evaluated in accordance with its success in educating the "normal" child.254 The model of program parity provides one theoretical foundation for consensus. It seeks to bridge the gap opened by the necessary creation of particularized rights for members of one disadvantaged group, by interpreting those rights in light of the legitimate goals and values of the institution of public education within which those rights must be implemented.

Although program comparisons of the kind suggested in this article may seem unwieldy and impractical as a legal standard to resolve litigated cases, such cases are rare. ${ }^{255}$ Rough comparisons by teachers and administrators who know their school system and its programs well may not be so difficult. School officials are accustomed to balancing priorities, setting goals, and making budgets with respect to numerous potentially conflicting interests. Within the broad flexibility of the substantive standard of the EAHCA and the Board of Education $v$. Rowley decision, ${ }^{256}$ the understanding of the public educational obligation to the handicapped by these service providers is very important. Program parity defines this obligation in terms that are meaningful to schools. This concept maintains a special legal process for the handicapped that takes into account the special and individualized needs of the handicapped. It sets this process in a framework for decisionmaking that recognizes competing valuable interests and goals and mediates the tension between them. Handicapped children have individual, enforceable rights to education, but the program parity approach defines the content of these rights by reference to the collective decisions made for all others. Their educational programs are based on need, but the cost of those programs may be taken into account so as not to require unreasonable sacrifices by those seeking to progress according to their merits. A unitary federal standard is defined, but that standard relates not to content or level of education generally, but rather to the federal interest in parity of treatment.

Great flexibility in local educational systems is still allowed under this model-flexibility in the general level of education, in the choice of educational methods to be used, and in the opportunity for experimentation. This flexibility is subject to one substantive constraint, the constraint which most accurately reflects the limited nature of the legitimate federal concern for public education: that the handicapped should not be disadvantaged with

254. See supra note 7 and accompanying text.

255. Neal \& Kirp, supra note 72 , at 77.

256. 458 U.S. 176 (1982); see Note, The Rowley Decision, supra note 11, at 702-04. 
respect to the nonhandicapped in their pursuit of an education of the highest possible quality.

In addition to providing a framework for resolving resource allocation issues in a way that reduces the tensions between the EAHCA and the public education system within which it must be implemented, the model of program parity provides incentives for local school personnel to adopt a broad equitable approach to program design. An approach that centers entirely on a case-by-case review of the educational programming of individual children whose parents dispute a programming decision encourages the squeaky wheel approach to educational programming, under which the most vocal parents obtain the best educational services for their children. ${ }^{257}$ When the legal system demonstrates a respect for sound and equitable program-wide resource allocation/programming decisions, school administrators will be able to devote greater attention to overall program development and greater equity in programming decisions. ${ }^{258}$

In the final analysis, the concept of program parity is most important as a model for nonlegal decisionmaking by professional educators. Implementation of fair and equitable decisionmaking in education depends primarily upon a commitment by these personnel to certain ideals-ideals that are philosophical and political as well as educational. These ideals must be sufficiently clear and fair-minded to command respect. Program parity expresses one such set of ideals.

257. See Kirst \& Bertken, Due Process Hearings in Special Education: Some Early Findings from Califormia, in Special Education Policies 136, 154 (Chambers \& Hartman eds. 1983) (showing key to receiving educational benefits under the EAHCA is willingness to contest school district decisions).

258. Cf. Clune, A Political Mode of Implementation and Implications of the Model for Public Policy Research, and the Changing Roles of Law and Lawyers, 69 IowA L. REv. 47, 123 (1983) (role of legal rights created by "political law" is "to set the stage for creative and adaptive social programs").

I am grateful to Jack Nance, Director of Special Programs in the Wake County School System in North Carolina, for confirming this point at the February 24-25, 1984, conference held at Duke Law School in connection with this symposium issue. 